\begin{tabular}{l|l|l}
\hline Vol. 24(4):369-389 & Ocean and Polar Research & December 2002 \\
\hline
\end{tabular}

\title{
Article
}

\section{Hydrography around Dokdo}

\author{
Kyung-Il Chang*, Youn-Bae Kim, Moon-Sik Suk, and Sang-Kyung Byun \\ Global Environment Research Laboratory, KORDI \\ Ansan, P.O. Box 29, Seoul 425-600, Korea
}

\begin{abstract}
CTD data taken in the Ulleung Basin between 1996 and 2001 are analyzed to understand the hydrography around Dokdo. Major features occurring in the Ulleung Basin such as the path variability of the East Korean Warm Current (EKWC), the location and size of the Ulleung Warm Eddy (UWE), and the position of the Offshore Branch along the Japanese coast all influence the hydrography around Dokdo. The Dokdo area frequently lies in the eastern part of the meandering EKWC and the UWE that results in a tilting of isolines sloping upwards to Dokdo in the Ulleung Interplain Gap (UIG) between Ulleungdo and Dokdo. Subsurface water near Dokdo then becomes colder and less saline than water near Ulleungdo. Two cases that are opposite to this general trend are also identified when the Dokdo area is directly affected by the EKWC and by a small scale eddy fed by the Offshore Branch. High salinity cores and warm waters are then found near Dokdo with isolines sloping upwards to Ulleungdo. Freshening of the East Sea Intermediate Water was observed in the UIG when neither the EKWC nor the UWE was developed in the Ulleung Basin during June-November 2000.
\end{abstract}

Key words : Dokdo, Ulleung Interplain Gap, East Sea, Hydrography, East Korean Warm Current, Ulleung Warm Eddy.

\section{Introduction}

The East Sea is divided into the $4000 \mathrm{~m}$ deep Japan Basin (JB) in the northern half, the Ulleung Basin (UB) in the southwest and the Yamato Basin (YB) in the southeast, each about $2200 \mathrm{~m}$ deep (Fig. 1). Dokdo is located in the southwestern East Sea and plays a topographically important role in basin-to-basin deep water exchanges along with surrounding shallow bottom topography. The Ulleung Interplain Gap (UIG) is an abyssal channel between Dokdo and Ulleungdo and serves as a conduit of deep waters between the JB and the UB. The UIG is about $90 \mathrm{~km}$ wide and nearly a symmetric channel with a maximum depth of about 2300 $\mathrm{m}$. The Oki Bank between Dokdo and Oki Island acts as a barrier for the deep water exchange between the UB and YB. The Korea Plateau lying between the JB and the UB limits the deep water exchange between the JB and UB. The Oki Bank and Korea Plateau also affect the upper

${ }^{*}$ Corresponding author. E-mail : kichang@kordi.re.kr layer circulation (e.g., Hogan and Hurlburt, 2000).

The East Sea is connected with the East China Sea through the Korea Strait in the southwest, with the North Pacific through the Tsugaru Strait in the east, and with the Sea of Okhostk through the Soya Strait in the northeast and Tartarskiy Strait in the north. As these straits are all shallower than $200 \mathrm{~m}$, water exchanges with adjacent seas and the North Pacific Ocean are limited to the upper 200 $\mathrm{m}$. Below the surface layer distinct deep water masses are formed, modified and circulate within the East Sea.

The subpolar front at about $40^{\circ} \mathrm{N}$ in the East Sea separates the southern warm water region, which is strongly stratified, from the northern cold water region where weak stratification develops only in summer. Three water masses are found south of the subpolar front: the Tsushima Current Water (TCW), East Sea Intermediate Water (ESIW), and the East Sea Proper Water (ESPW). The Tsushima Current (TC), a branch of the Kuroshio, carries the warm and saline TCW into the East Sea through the Korea Strait and then splits into two distinct branches: one flowing northeastward along the western 
(a)
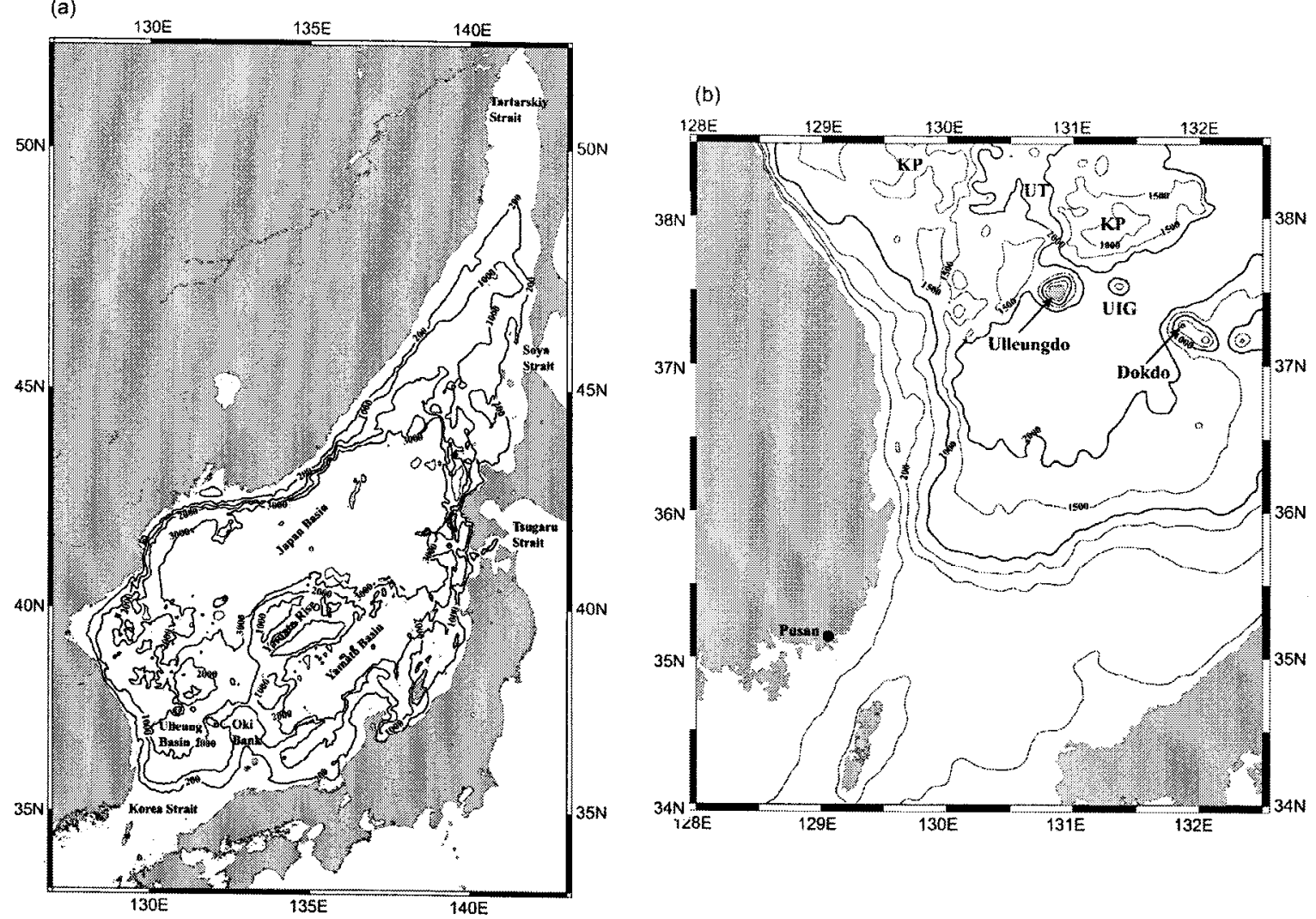

Fig. 1. (a) A topographic map of the East Sea with isobaths of $200 \mathrm{~m}, 1000 \mathrm{~m}, 2000 \mathrm{~m}$, and $3000 \mathrm{~m}$. Three deep basins and four straits through which surface waters are exchanged with adjacent sea areas are also shown together with major topographic features referred to in the text. (b) A topographic map of the Ulleung Basin with isobaths of $100 \mathrm{~m}, 200 \mathrm{~m}, 500 \mathrm{~m}, 1000 \mathrm{~m}, 1500 \mathrm{~m}$, and $2000 \mathrm{~m}$. UIG, KP, and UT denote the Ulleung Interplain Gap, Korea Plateau, Ulleung Trough, respectively.

coast of Japan called Nearshore Branch, and another northward along the east coast of Korea that has been called the East Korean Warm Current (EKWC) since Uda (1934). The Offshore Branch (OB), fed by the TC through the western channel of the Korea Strait, flows to the northeast following the Japanese continental shelf break seaward of the Nearshore Branch (Hase et al., 1999). The $\mathrm{OB}$ has been known to exist in summer and fall when the transport of the TC becomes large (Kawabe, 1982). A recent long-term observation, however, showed the OB exists all the year round (Mitchell et al., 2002). The TCW occupies the upper $200 \mathrm{~m}$ and can be identified by high salinity core(s) capped in summer by low salinity water. The northward flowing EKWC separates from the Korean coast at around $37-38^{\circ} \mathrm{N}$ and forms an anticyclonic warm ring called the Ulleung Warm Eddy (UWE; An et al., 1994; Shin et al., 1995; Suh et al., 1999) or Ulleung Warm Lens (Cho et al., 1990). Trajectories of satellite- tracked drifters indicate that the life time of the UWE is about 10 months (Lie et al., 1995). Continuous acoustic travel-time measurements for two years between June 1999 and June 2001 showed that the UWE was present for 20 consecutive months (Mitchell et al., 2002).

The ESIW, found below the TCW, is characterized by low salinity and high dissolved oxygen contents. In the UB this shallow salinity minimum layer has two sources: one is an extension of the southward flowing North Korean Cold Water along the east coast of Korea, and the other is north of Ulleungdo (Kim and Kim, 1983; Kim and Chung, 1984; Kim et al., 1991; Cho and Kim, 1995; Shin et al., 1998). Property definitions differ slightly from author to author probably due to the seasonal and interannual variability (Kim et al., 1991; Kim et al., 1999). ESIW was defined by salinity less than 34.06 , potential temperature $(\theta) \quad 1.0-5.0^{\circ} \mathrm{C}$ and potential density $\left(\sigma_{\theta}\right)$ 26.9-27.3 $\mathrm{kg} \mathrm{m}^{-3}$ by Kim and Kim (1999). 
Below the ESIW lies the ESPW, a thick homogeneous water mass with temperature less than $1.0^{\circ} \mathrm{C}$, which was first identified by Uda (1934). The ESPW was believed to be a single water mass until the $1970 \mathrm{~s}$, but recent studies show that it consists of two or more waters (Nitani, 1972; Kim et al., 1996).

The maximum depth of the UB exceeds $2000 \mathrm{~m}$, and waters below about $200 \mathrm{~m}$ depth originate neither locally, since minimum surface temperature in winter is well above $8^{\circ} \mathrm{C}$, nor from the Korea Strait. Both the ESIW and the ESPW found in the UB, therefore, are thought to originate in the $\mathrm{JB}$ where the winter surface temperature falls below $1.0^{\circ} \mathrm{C}$. They spread towards the UB over the Korea Plateau between the Korean coast and Ulleungdo (Cho and Kim, 1995; Shin et al., 1998), and through the UIG (Kim et al., 1991).

A recent long-term continuous subsurface temperature measurement revealed that the hydrography around Dokdo is highly variable depending on the spatial and temporal variability of the EKWC, the UWE, the subpolar front, and the OB (Mitchell et al., 2002). This paper attempts to understand factors affecting the hydrography around Dokdo by analyzing CTD data taken in the UB and around Dokdo since 1996.

\section{Data and method}

Eleven CTD surveys were conducted in the UB during 1996-2001 (Table 1). Nine surveys covered a wide area in the UB, and ten surveys were made at 5-10 stations across the UIG between Ulleungdo and Dokdo (Fig. 2d). The surveys in the UIG were made mainly in spring (AprilMay) and fall (Sept.-Nov.) with one summertime observation in 1996. CTD was lowered to near the seabed since the survey in Oct. 1998 while the observation was made only to $500 \mathrm{~dB}$ in the UIG before Oct. 1998. CTD surveys specifically focused on the detailed hydrography around Dokdo were made 3 times in Aug. 1996, Sept.-Oct. 1999, and May 2000 with star-shaped CTD stations around Dokdo. The observation in May 2000, however, was limited to the southern Dokdo due to a trouble in CTD. During the surveys around Dokdo, CTD was lowered to $500 \mathrm{~dB}$ at most stations (denoted by "shallow" in Table 1) with the exception of several stations where CTD was lowered to near the seabed in Sept.-Oct. 1999 (denoted by "full" in Table 1). We analyze the data in this paper taken in Aug. 1996, Oct. 1999, and May 2000 when the survey areas include both a wide area in the UB and the area around Dokdo (Fig. 2a-2c). CTD data taken across the UIG (Fig. 2d) are also analyzed. Figures 3 and 4 shows satellite-derived sea surface temperature (SST) distributions taken at the time of each CTD survey.

SBE 911 CTD was used in all measurements with identical temperature and conductivity sensors that have been post-calibrated once or twice a year by sending them to SeaBird Co.. CTD data were accordingly calibrated using post-calibration sheets except for data taken in 1997 that we were not able to find raw data for the post-

Table 1. Summary of CTD observations conducted in the Ulleung Basin, Ulleung Interplain Gap, and around Dokdo since 1996.

\begin{tabular}{|c|c|c|c|}
\hline Observation period & Observation area & CTD lowering depth & Post-calibration \\
\hline Aug. 2-18, 1996 & UB, UIG, Dokdo & $\begin{array}{l}\text { UB: full, shallow } \\
\text { UIG, Dokdo: shallow }\end{array}$ & 0 \\
\hline Apr. 1997 & UIG & shallow & $x$ \\
\hline Oct. 1997 & UB, UIG & shallow, full & $x$ \\
\hline Oct. 1998 & UB, UIG & full & $\bigcirc$ \\
\hline May 1999 & UIG & full & O \\
\hline Sept. 28-Oct. 16, 1999 & UB, Dokdo & $\begin{array}{l}\text { UB: full } \\
\text { Dokdo: shallow, full }\end{array}$ & 0 \\
\hline May 5-29, 2000 & UB, UIG, Dokdo & $\begin{array}{l}\text { UB, UIG: full } \\
\text { Dokdo: shallow, full }\end{array}$ & 0 \\
\hline Sept. $25-30,2000$ & UB, UIG & full & 0 \\
\hline Nov. $3-10,2000$ & UB, UIG & $\begin{array}{l}\text { UB: shallow } \\
\text { UIG: full }\end{array}$ & O \\
\hline Apr. 10-24, 2001 & UB, UIG & $\begin{array}{l}\text { UB: shallow } \\
\text { UIG: deep }\end{array}$ & O \\
\hline Oct. 12-21, 2001 & UB, UIG & $\begin{array}{l}\text { UB: shallow } \\
\text { UIG: deep }\end{array}$ & $\mathrm{O}$ \\
\hline
\end{tabular}



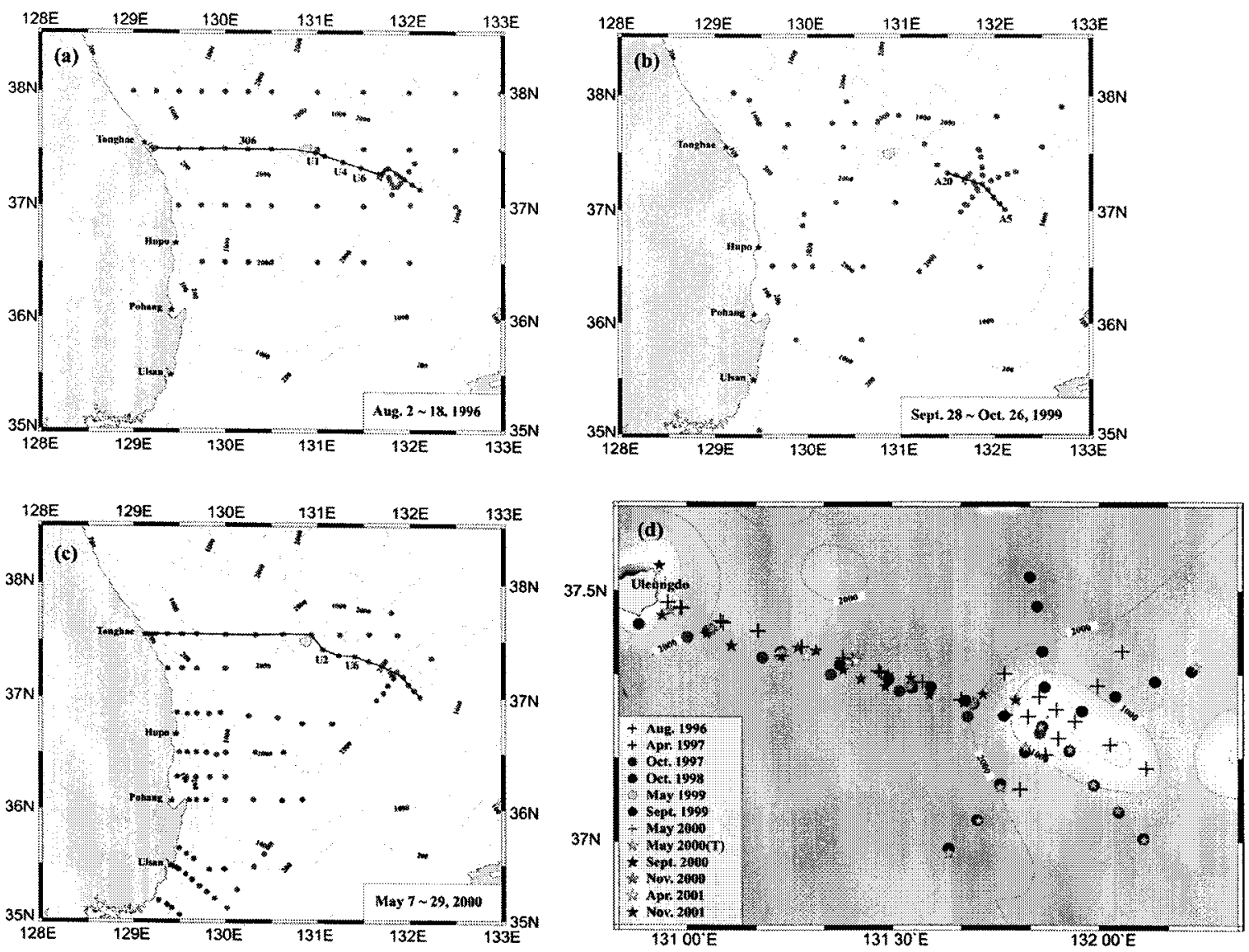

Fig. 2. CTD stations occupied in the Ulleung Basin and around Dokdo (a) in August 1996, (b) between September and October 1999, (c) in May 2000. (d) CTD stations occupied in the Ulleung Interplain Gap between Ulleungdo and Dokdo and around Dokdo during 1996-2001.

calibration. CTD data processing closely followed the suggestion by Kim et al. (2000). Accuracies of SBE 911 $\mathrm{CTD}$ are $\pm 0.001^{\circ} \mathrm{C}$ in temperature and \pm 0.0015 in salinity with their respective resolutions of $0.0002^{\circ} \mathrm{C}$ and 0.0004

\section{Results}

Vertical structure of temperature and salinity near Dokdo

Monthly variation of vertical profiles of $\theta$ and salinity is investigated at a CTD station within $10 \mathrm{~km}$ northwest of Dokdo (Fig. 5a). Winter profile near Dokdo is unavailable, and the profile in Feb. 1997 is for a station at about $35 \mathrm{~km}$ apart from Dokdo to northeast.

Surface temperature shows its respective maximum and minimum in August $\left(\theta=27.5^{\circ} \mathrm{C}\right)$ and February $\left(\theta=10.2^{\circ} \mathrm{C}\right)$ with an annual amplitude of about $17.0^{\circ} \mathrm{C}$. A thick surface mixed layer (SML) is developed in Feb. with an annual maximum mixed layer depth (MLD) of $65 \mathrm{~dB}$, when the
MLD is defined by a depth where temperature becomes $1.0^{\circ} \mathrm{C}$ lower than the surface temperature. The SML shoals in spring and summer with minimum MLD of $5 \mathrm{~dB}$ in August. Deepening of the SML then occurs in fall. In general, temperature decreases sharply below the SML except in Feb. when temperature slowly decreases down to $120 \mathrm{~dB}$. Major seasonal variation of temperature is confined within the upper $300 \mathrm{~dB}$. Relatively homogeneous subsurface layers in temperature were found between 30$60 \mathrm{~dB}$ below the seasonal thermocline in May 1999 and in August 1996. Another subsurface thermostad thicker than $50 \mathrm{~dB}$ also appeared between 100-150 dB in August 1996 resulting in a two-layer structure below the seasonal thermocline and above $200 \mathrm{~dB}$. Temperature below 80 $\mathrm{dB}$ and even below $300 \mathrm{~dB}$ is higher in Aug. 1996 than in other times due to the subsurface thermostad. The thermostad arises due to the presence of an anticyclonic warm eddy in the UIG which will be described shortly.

Surface salinity is higher than 34.2 in winter and spring, 


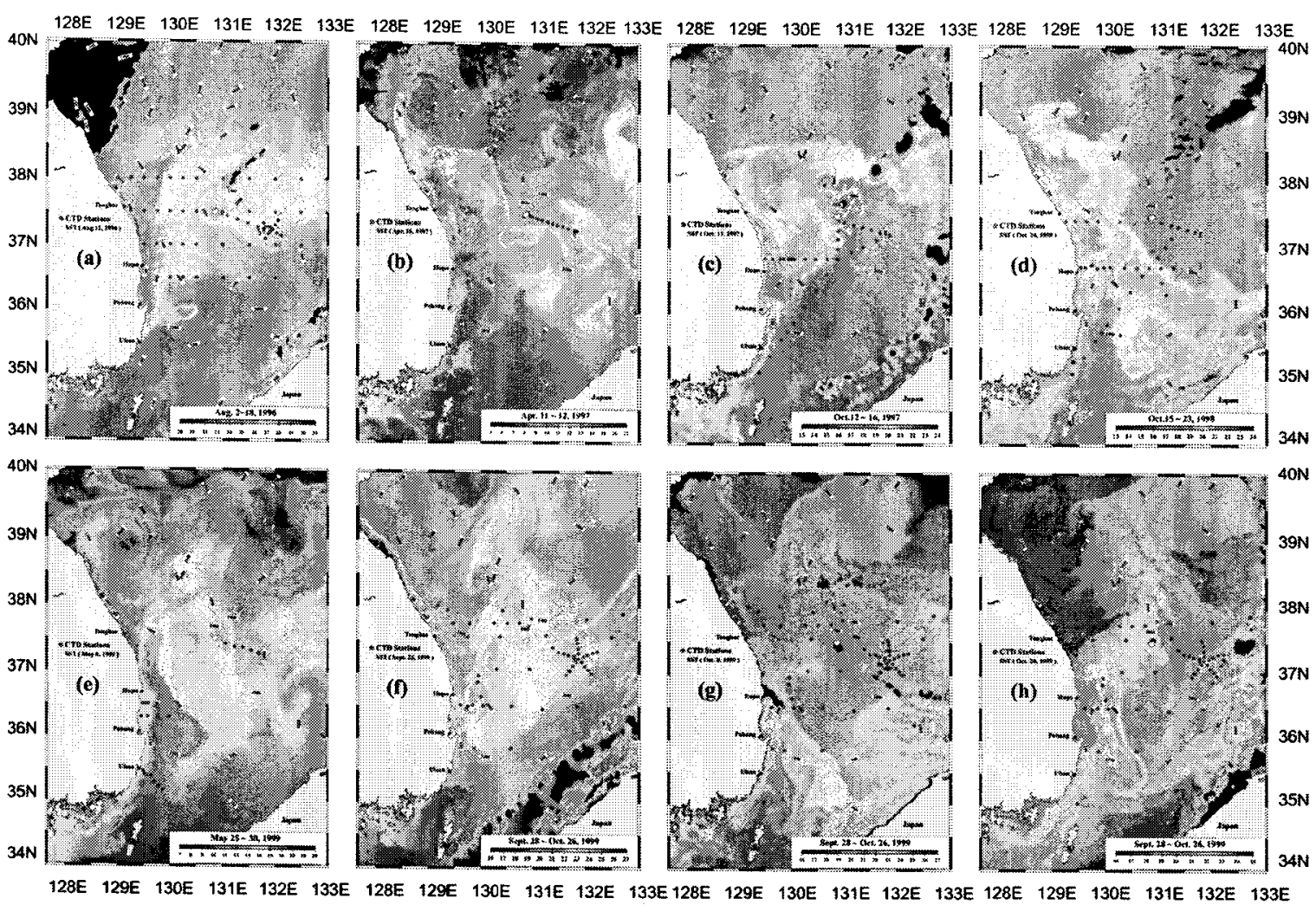

Fig. 3. Satellite-derived sea surface temperature (SST) distributions taken at or near the time of CTD surveys on (a) August 12, 1996, (b) April 16, 1997, (c) October 13, 1997, (d) October 24, 1998, (e) May 6, 1999, (f) September 25, 1999, (g) October 8, 1999, and (h) October 20, 1999. CTD stations are at each survey are also shown with closed circles.

and lowered by more than 1.0 in summer and fall. High salinity cores $(S>34.1)$ are found below halocline in stratified seasons, and both the high salinity water and the overriding low salinity water are thought to be brought into the area through the Korea Strait by the TC. Salinity in the subsurface thick thermostad found in Aug. 1996 is higher than 34.4, indicative of the influence of the TCW capped by low salinity water at the surface. The ESIW characterized by a salinity minimum layer below the high salinity core is also recognizable and most prominent in Nov. 2000. The salinity minimum layer is found at a deeper depth in Aug. 1996 than in other times.

Vertical profiles of temperature and salinity at nearly the same location northwest of Dokdo in Oct. 1997, 1998, and 2001 are shown in Fig. 5b. Year-to-year variation of surface salinity and temperature range 32.85-33.51 and $20.05-20.97^{\circ} \mathrm{C}$, respectively. Temperature sharply decreased in 1998 and 2001 below the SML, while it decreased rather smoothly down to about $150 \mathrm{~dB}$ in 1997 . Consequently, subsurface temperature is higher in 1997 than in both 1998 and 2001 in the upper $400 \mathrm{~dB}$. A thick high salinity core was found in Oct. 1997. The vertical profiles in Oct. 1997 is similar to those in Aug. 1996, suggesting that the sea area close to Dokdo was directly influenced by the warm and saline TCW as can be seen in Fig. 3c and Fig. $8 \mathrm{~b}$.

\section{Hydrography in the UB August 1996}

CTD survey in Aug. 1996 was split into two: one in the UB between $36.5-38^{\circ} \mathrm{N}$ during Aug. 2-11 followed by a local survey around Dokdo and in the UIG during Aug. 16-18 (Fig. 2a).

Figure 6 shows horizontal distribution of temperature and salinity at $5 \mathrm{~dB}$ and $100 \mathrm{~dB}$. Surface temperature is lower along the coast of Korea than offshore area east of about $130.5^{\circ} \mathrm{E}$. Surface temperature east of Ulleungdo is almost horizontally homogeneous between $25.0-26.0^{\circ} \mathrm{C}$ except for two stations east of Ulleungdo where surface temperature is below $25.0^{\circ} \mathrm{C}$ and surface salinity is slightly higher than surrounding waters. A band of low salinity water is found at $5 \mathrm{~dB}$ between $131-132^{\circ} \mathrm{E}$ passing 

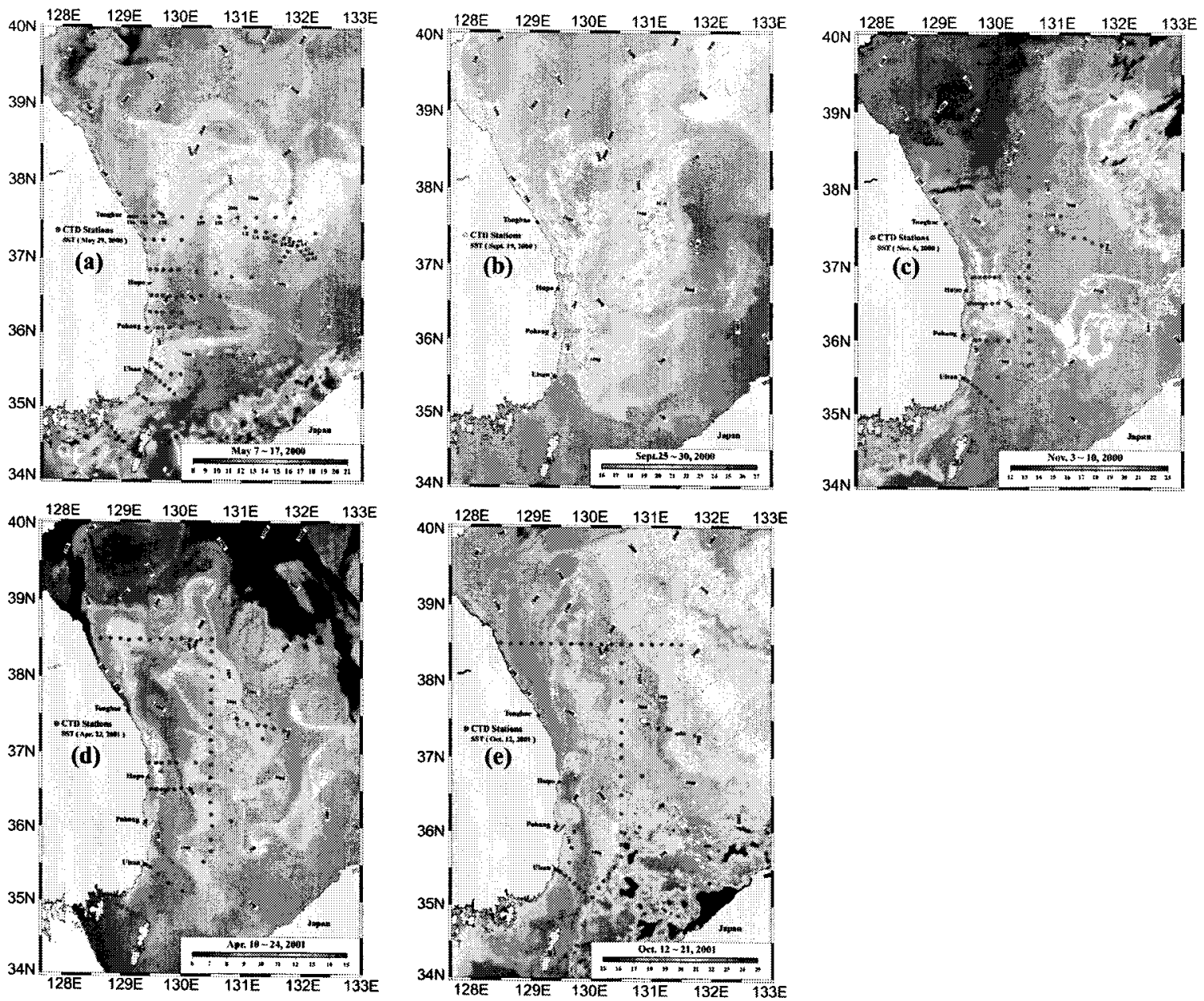

Fig. 4. Satellite-derived sea surface temperature (SST) distributions taken at or near the time of CTD surveys on (a) May 29, 2000, (b) September 19, 2000, (c) November 6, 2000, (d) April 22, 2001, and (e) October 12, 2001. CTD stations are at each survey are also shown with closed circles.

through the UIG. Low salinity water at the surface also appears off the Korean coast north of $37.5^{\circ} \mathrm{N}$. Temperature of the coastal low salinity water is about $3.0^{\circ} \mathrm{C}$ colder than the low salinity water in the offshore area.

Property distributions at $100 \mathrm{~dB}$ clearly shows the path of the TC carrying the warm and saline water (Fig. 6b). The distribution of warm and saline TCW at $100 \mathrm{~dB}$ closely parallels the distribution of surface low salinity band elongated in the meridional direction, suggesting that the TC entering the East Sea in a stratified season carries low salinity water at the surface and high salinity water below the seasonal pycnocline, the former called Tsushima Surface Water and the latter Tsushima Middle Water according to Kim and Kim (1983). The TCW extends to the northwest from the southeastern corner of the observation area. The TCW lies apart about $100 \mathrm{~km}$ from the east coast of Korea and forms a thermohaline front with low temperature and salinity $\left(\theta<5.0^{\circ} \mathrm{C}, \mathrm{S}<\right.$ 34.1) coastal water. The $10.0^{\circ} \mathrm{C}$ isotherm running to the northwest turns to the northeast towards the UIG north of $37^{\circ} \mathrm{N}$ and a high salinity core occurs in the middle of the UIG. Cold and less saline water $\left(\theta<6.0^{\circ} \mathrm{C}, \mathrm{S}<34.2\right)$ in the northeastern TCW extends to the southwest resulting in the relatively cold and less saline water around Dokdo. Temperature and salinity in the Dokdo vicinity is further lowered by about $1.0^{\circ} \mathrm{C}$ and 0.1 , respectively, presumably due to the effect of shoaling topography around Dokdo. It can be seen from Fig. 7 that isolines are locally lifted around Dokdo.

Shown in Fig. 7 are vertical distributions of $\theta$, salinity and $\sigma_{\theta}$ along a section shown in Fig. 2a. A homogeneous layer is found in a temperature range of $9.0-11.0^{\circ} \mathrm{C}$ in the 
(a)
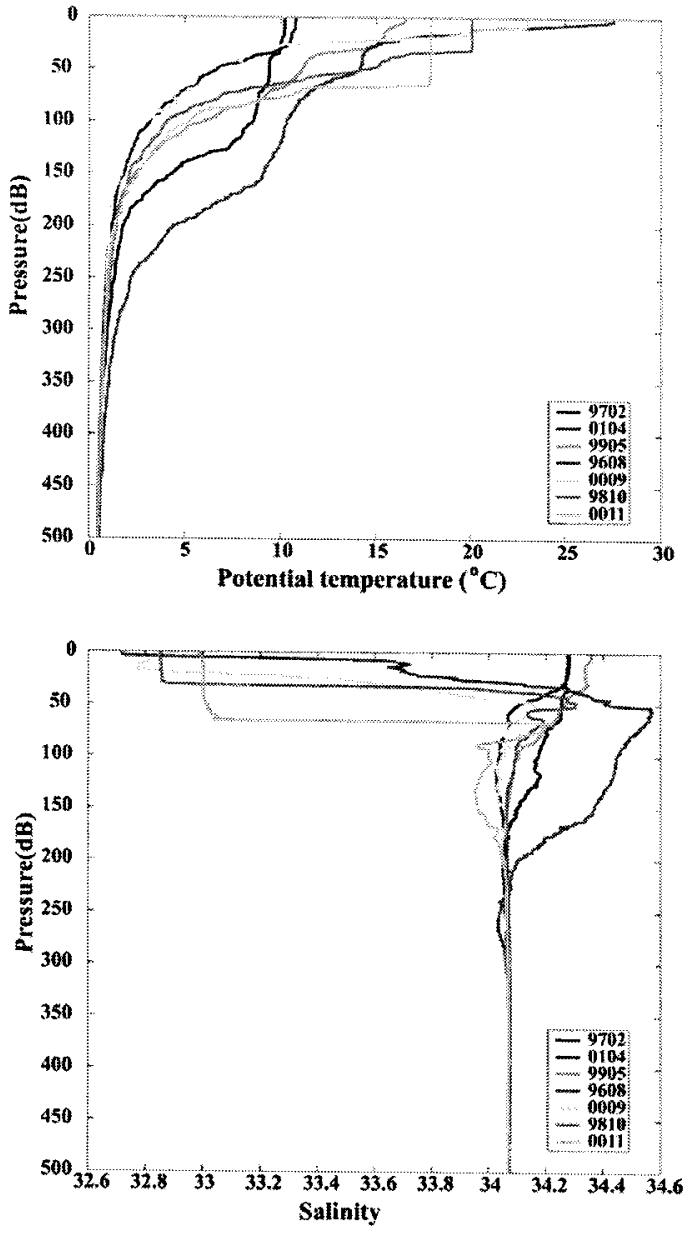

(b)
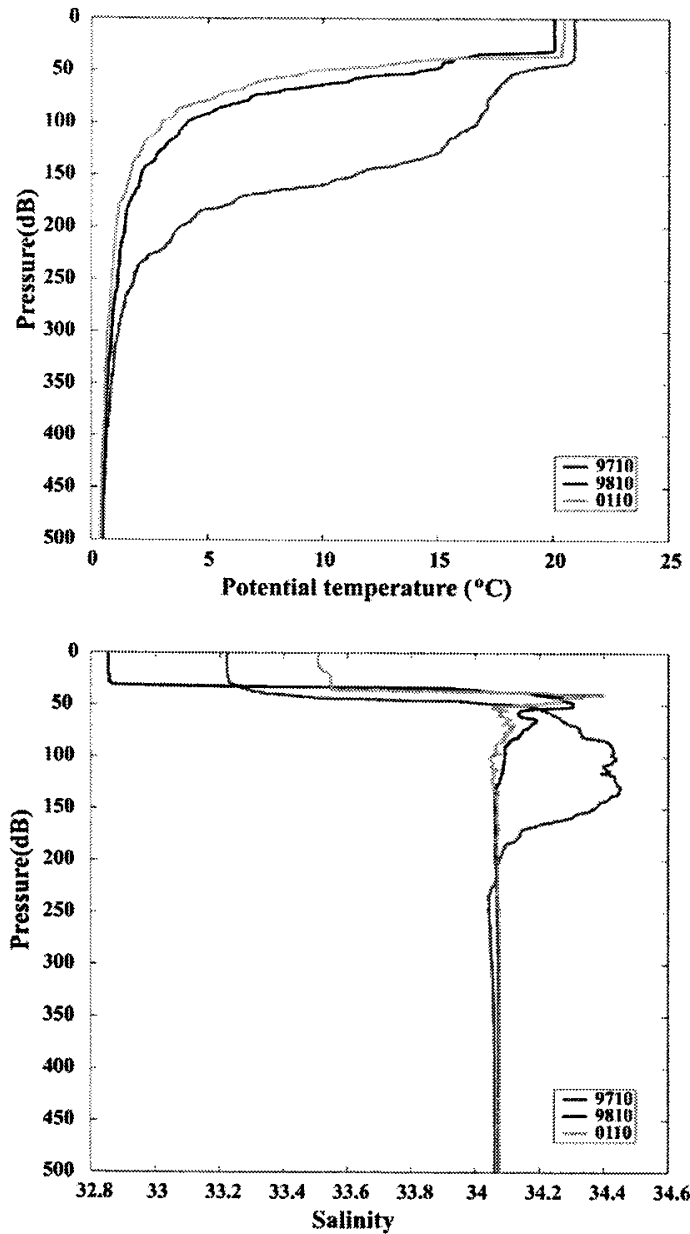

Fig. 5. (a) Monthly variation of vertical profiles of potential temperature (upper panel) and salinity (lower panel) near Dokdo. (b) Vertical profiles of potential temperature (upper panel) and salinity (lower panel) near Dokdo in October 1997, 1998, and 2001.

UIG. Isolines in the lower portion of and below the homogeneous layer $\left(\theta \leq 10.0^{\circ} \mathrm{C}, \mathrm{S} \leq 34.4\right)$ are bowl-shaped with its center in the middle of the UIG. The bowl-shaped isolines are extended to the maximum CTD lowering depth of $500 \mathrm{~dB}$ in the UIG. Salinity in the homogeneous layer is higher than 34.4 indicating its origin is the TCW. Salinity of surface water above the TCW is lower than the surface water in other regions where the TCW is not found. The vertical scale of the homogeneous layer is about 110 $\mathrm{dB}$ in its center and becomes about halved near Ulleungdo and Dokdo. The vertically homogeneous subsurface layer seen near Dokdo in Fig. 5 is due to the presence of this warm and salty homogeneous layer. The shape of isolines suggest an anticyclonic circulation in the UIG. The horizontal distribution of $\theta$ at $100 \mathrm{~dB}$ indicates that multiple bifurcations of the TC occur while it continues to flow to the northwest and exits the UB. The bifurcation occurs at $36.5^{\circ} \mathrm{N}, 37^{\circ} \mathrm{N}$, in the UIG, and $38^{\circ} \mathrm{N}$. The bifurcated $\mathrm{TCW}$ either forms anticyclonic eddies or turns to the southeast forming a meander. The TCW enters the UB east of 131 ${ }^{\circ} \mathrm{E}$, and it is not clear which branch of the TC, the EKWC or the $\mathrm{OB}$, carries the warm and salty water.

The influence of the TCW can be barely seen in a wide area from the Korean coast to an area offshore of Ulleungdo. The $1.0^{\circ} \mathrm{C}$ isotherm that is bowl-shaped in the UIG slopes downward from station 306 to the Korean coast (Fig. 7). A thick isothermal layer with $\theta$ ranging $1.0-2.0^{\circ} \mathrm{C}$ can be seen near the coast that coincides with the occurrence of a salinity minimum layer due to the ESIW hugging the coast. The ESIW with salinity less than 34.06 is also found in the UIG and near Dokdo, but the minimum salinity ( $<$ 34.00 ) in the ESIW occurs near the Korean coast. 
(a)

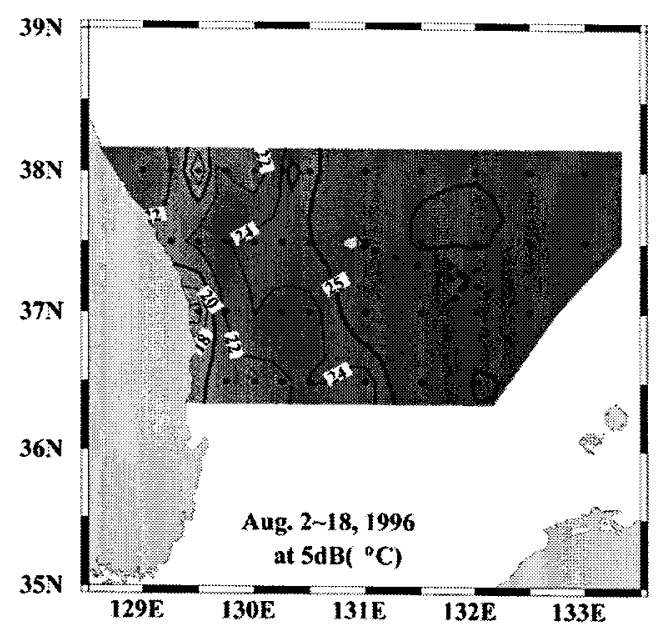

(b)

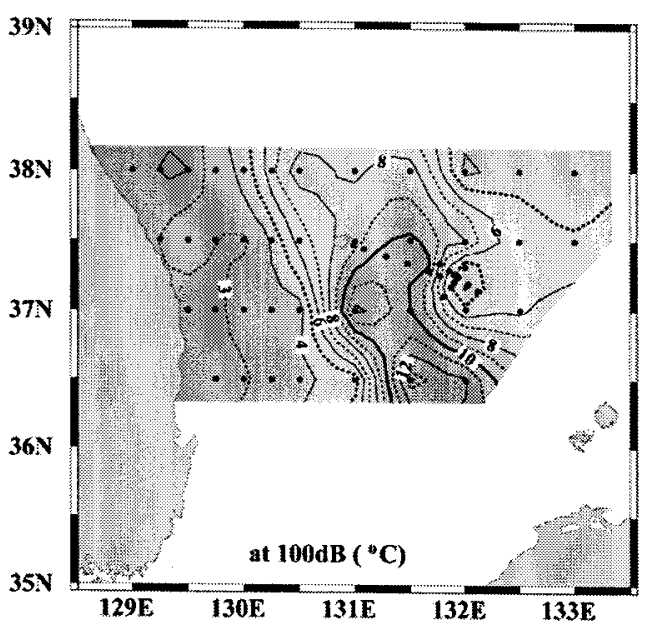

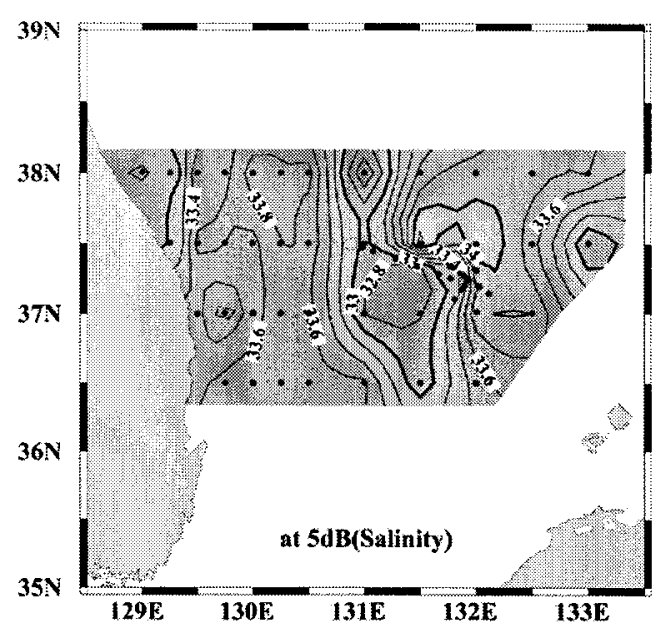

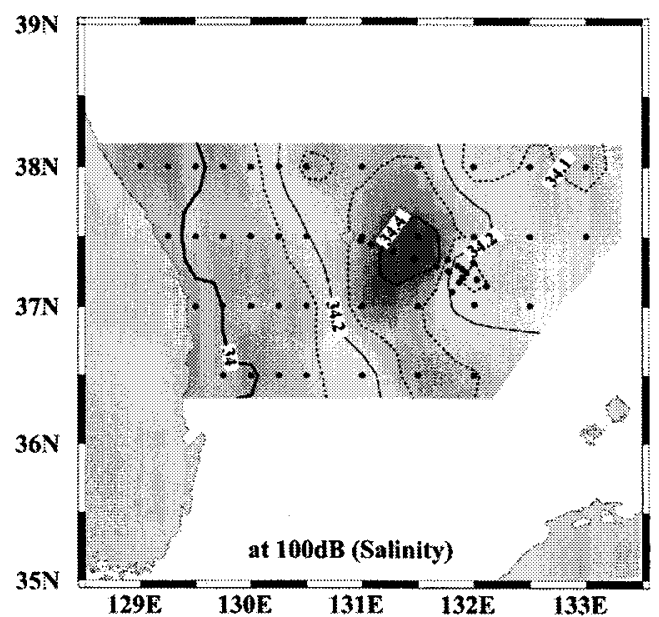

Fig. 6. Horizontal distribution of potential temperature (left panel) and salinity (right panel) at (a) $5 \mathrm{~dB}$ and (b) $100 \mathrm{~dB}$ in August 1996.

\section{7}

Two CTD surveys were made in the UIG in April and Oct., 1997. TCW of high salinity $(\mathrm{S}>34.4)$ is found in the eastern UIG close to Dokdo both in April and October (Figs. 8a, 8b). The high salinity water is found in the upper $100 \mathrm{~dB}$ in April, while the core in October is topped by warm and low salinity water. Temperature ranges of the TCW are $10.0-14.0^{\circ} \mathrm{C}$ in April and $15.0-20.0^{\circ} \mathrm{C}$ in October. The existence of the TCW near Dokdo results in the tilting of isolines sloping upwards from the area near Dokdo to the west. The tilting of isopycnals suggests a northward flow across the UIG relative to $500 \mathrm{~dB}$ surface.

Although the saline TCW is observed near Dokdo both in April and October, its origin seems to be different if we look at satellite-derived SST (Sea Surface Temperature) distributions at the time of CTD surveys (Fig. 3b,c). SST distribution in October indicates that warm surface water entering into the East Sea through the Korea Strait moved directly to the northwest towards Dokdo. The warm surface water approached to the east coast of Korea after turning to the west in an area northeast of the UIG. On the other hand, SST distribution in April shows that the sea area around Dokdo was influenced by a small scale warm eddy fed by the $\mathrm{OB}$ along the Japanese coast.

\section{October 1998}

Full-depth CTD casts to near the bottom were made in the UIG for the first time in Oct. 1998. The TCW 


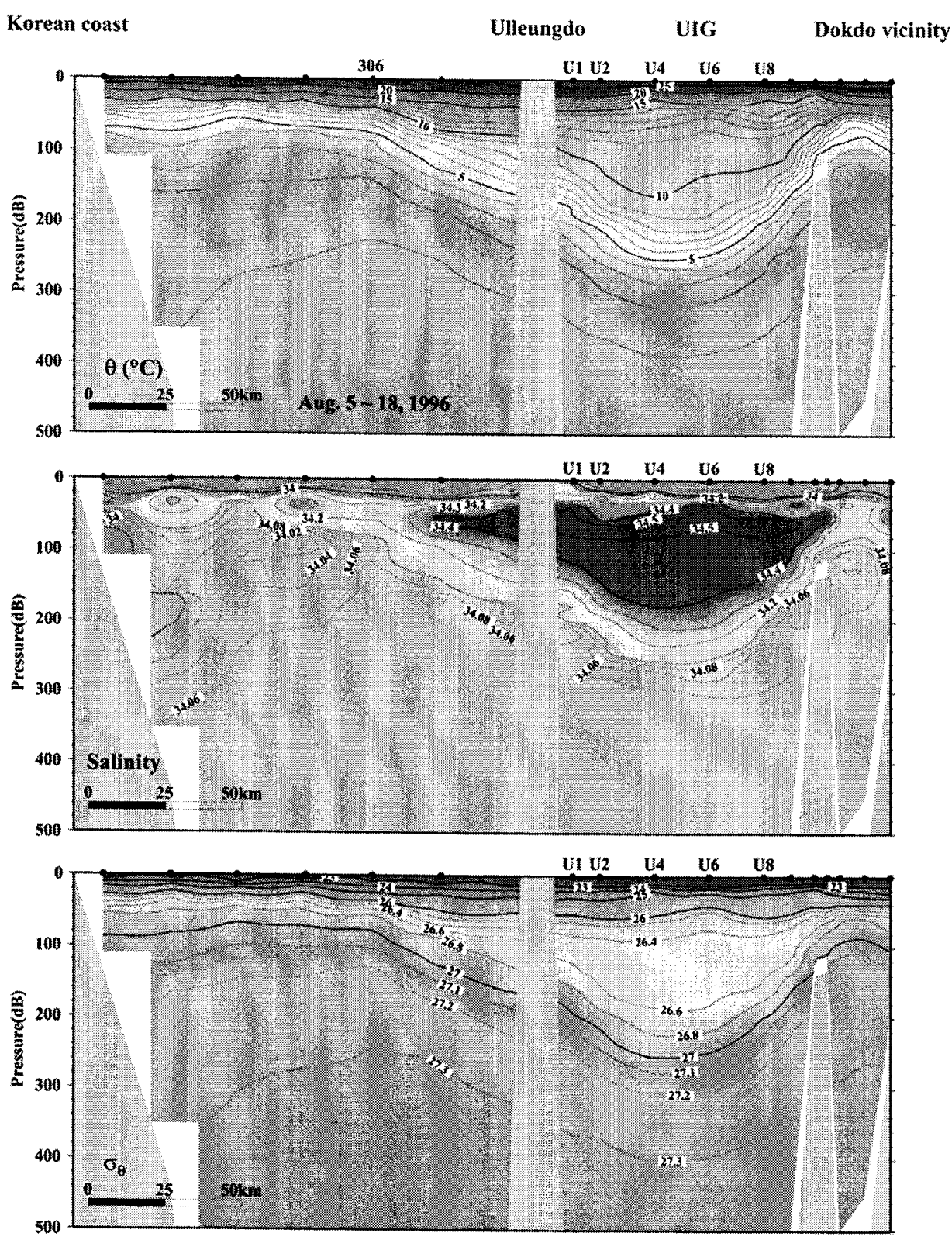

Fig. 7. Vertical distribution of potential temperature $(\theta)$, salinity, and potential density $\left(\sigma_{\theta}\right)$ along a section shown in Fig. 2a from the east coast of Korea to the Dokdo vicinity in August 1996. UIG denotes the location of the Ulleung Interplain Gap.

identified by a high salinity core below the halocline is found close to Ulleungdo, and isolines below the SML slope upwards and become more crowded towards Dokdo in contrast to the trend seen in Oct. 1997 (Fig. 8b). The vertical extent of the TCW core layer is shallower than that observed in Oct. 1997. SST distribution in Oct. 1998 (Fig. 3d) indicates that warm surface water mainly follows the east coast of Korea in the area west of Ulleungdo resulting in the relatively cold SST distribution around Ulleungdo and Dokdo as compared to the high SST in Oct. 1997 (Fig. 3c). The eastern edge of an anticyclonic warm eddy, which prevails in the UB, appears to be captured in the section. The tilting of isotherms sloping upwards to Dokdo occurs down to the bottom, hence the $0.1^{\circ} \mathrm{C}$ isotherm below $1500 \mathrm{~dB}$ is located deeper depth in the western part of the UIG than in its eastern part. 
(a)
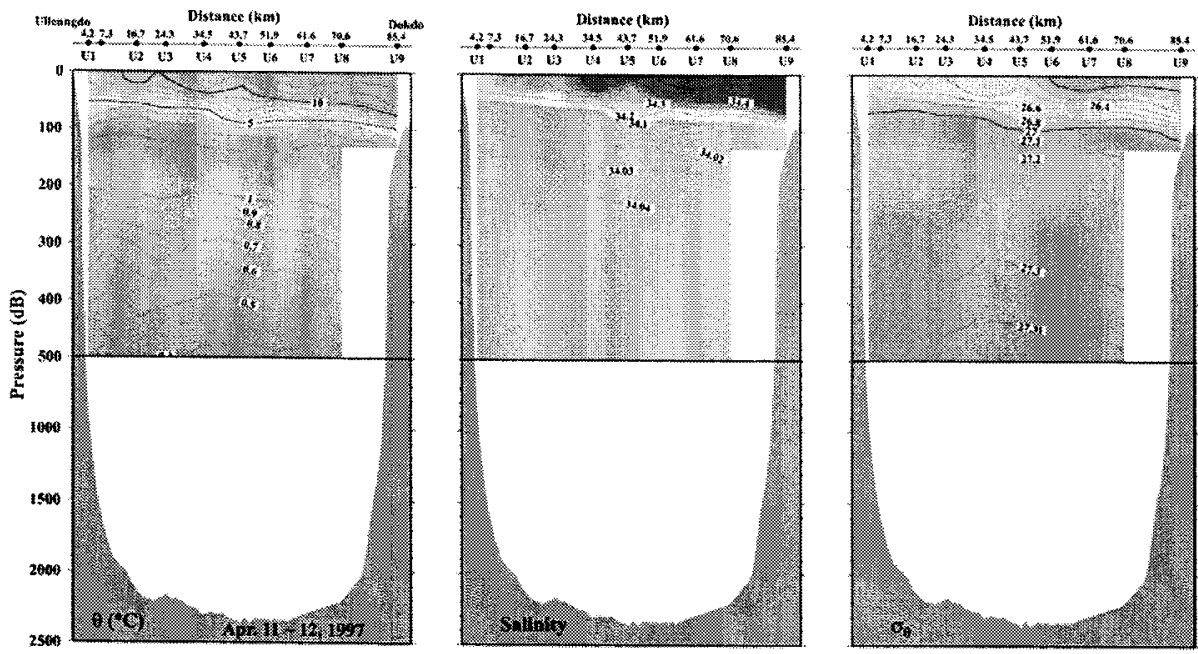

(b)
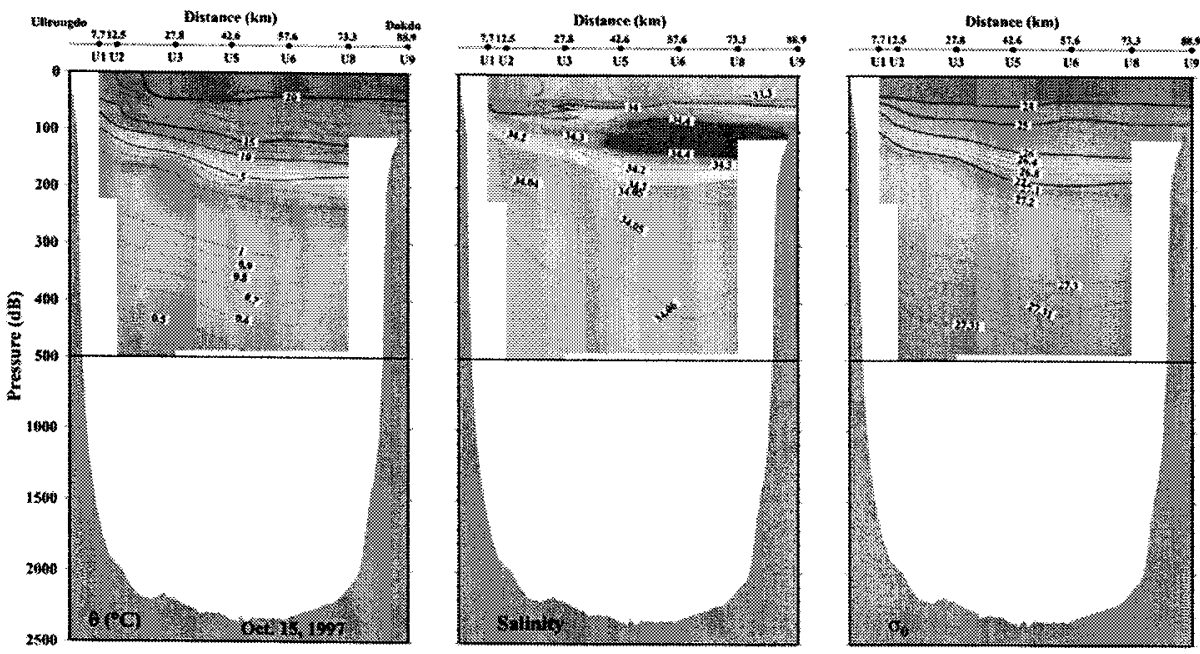

(c)
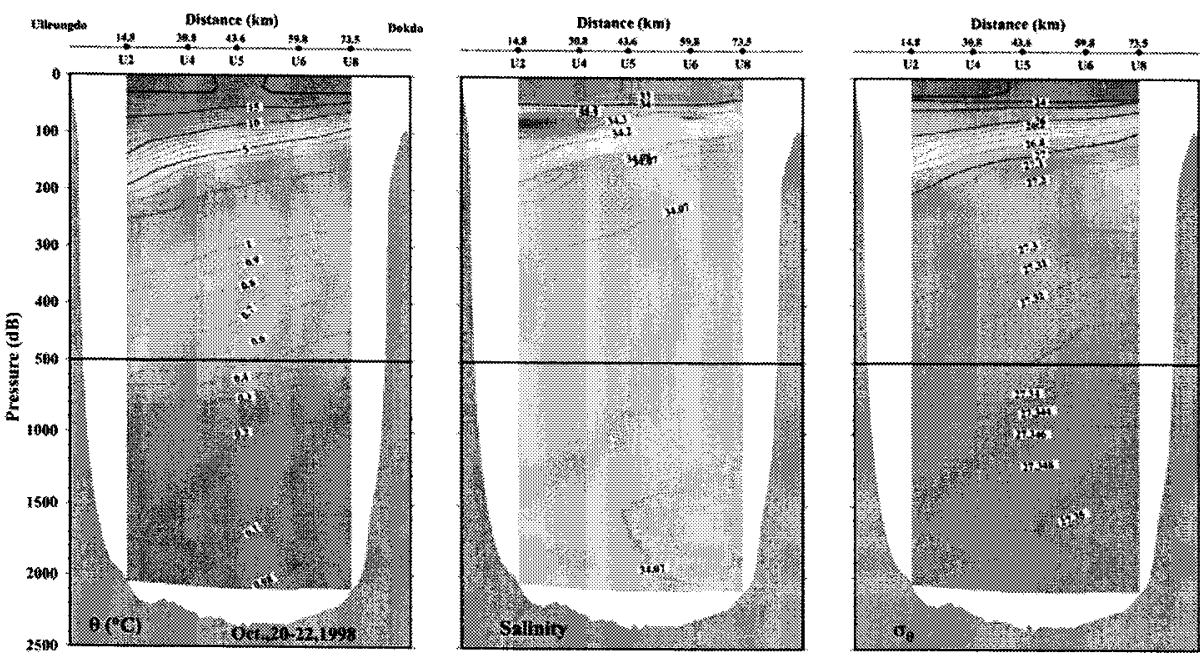

Fig. 8. Vertical distribution of potential temperature $(\theta)$, salinity, and potential density $\left(\sigma_{\theta}\right)$ across the Ulleung Interplain Gap between Ulleungdo and Dokdo in (a) April 1997, (b) October 1997, and (c) October 1998. The distance shown in the figure is measured from Ulleungdo to each station. 
1999

Closely spaced local CTD survey was conducted along 5 lines around Dokdo during Sept. 28-Oct. 2. Basin-wide CTD survey in the UB was also conducted 10 days after the local survey during Oct. 12-26 (Fig. 2b). Satellitederived SST images taken during the hydrographic surveys show a relatively rapid transition of surface temperature field (Fig. 3f,g,h). SST was relatively high in the Korea Strait and along the Japanese coast on Sept. 25. Surface warm water extended to the north along the Korean coast and separated from the coast at $37^{\circ} \mathrm{N}$ on Oct. 8 . Part of the separated warm water formed an anticyclonic eddy (UWE) and part of it flowed to the north in an area west of Ulleungdo. The northward flowing warm water turned to the east at $40^{\circ} \mathrm{N}$ and formed a large anticyclonic eddy. Smaller scale eddy also formed northeast of Ulleungdo. Surface warm water also broadly occupied an area east of $131^{\circ} \mathrm{E}$ due to the branch of the TC along the Japanese coast. The anticyclonic warm eddies draw cold water north of the subpolar front to the southwest, and a narrow band of cold surface water appears between the two branches of the warm TCW from the UIG towards the south along the eastern periphery of the UWE. The cold water region in the middle of the UB became broader on Oct. 24 and surface water became colder west of $133^{\circ} \mathrm{E}$. SST around Dokdo was relatively high due to the influence of the $\mathrm{OB}$.

Horizontal distributions of $\theta$ and salinity at $5 \mathrm{~dB}$ and (a)

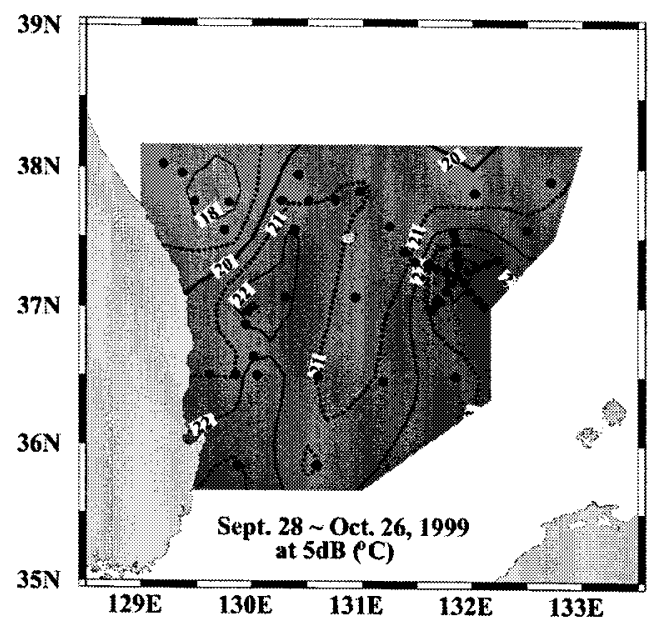

(b)

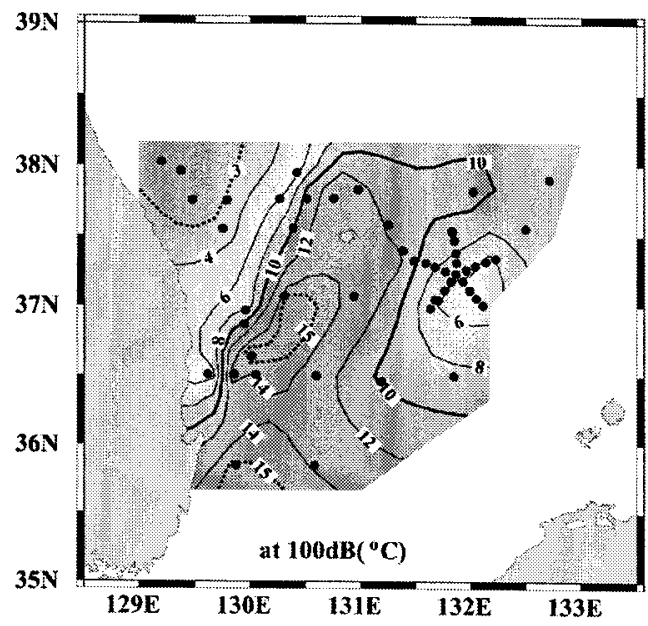

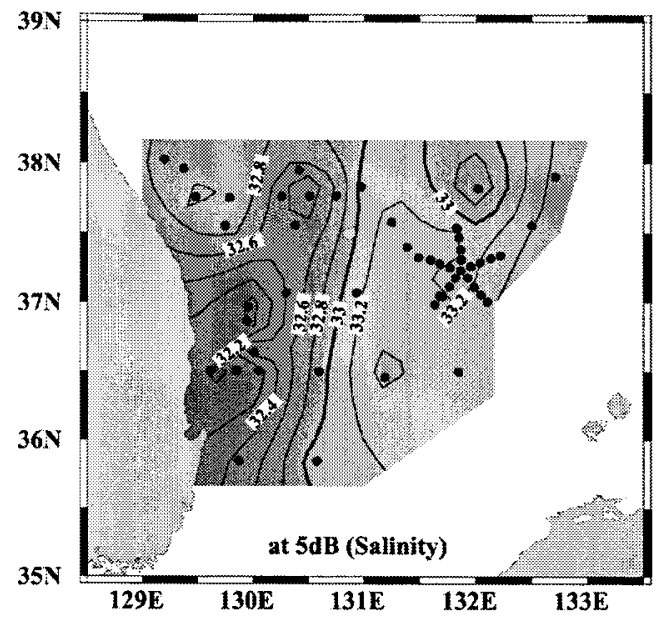

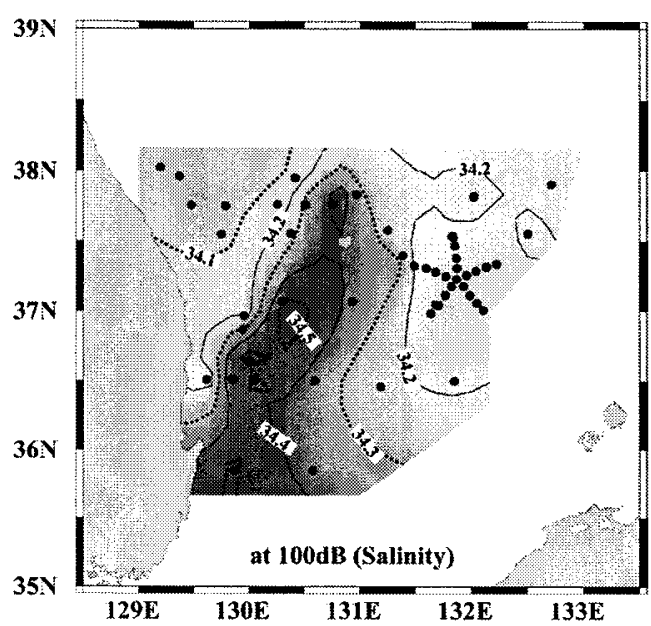

Fig. 9. Horizontal distribution of potential temperature (left panel) and salinity (right panel) at (a) $5 \mathrm{~dB}$ and (b) 100 dB in September-October 1999. 
$100 \mathrm{~dB}$ show that coldest surface water $\left(\theta<18.0^{\circ} \mathrm{C}\right)$ appear off the Korea coast north of $37.5^{\circ} \mathrm{N}$ (Fig. 9). Apart from the area occupied by the cold coastal water, relatively cold region with $\theta$ lower than $21.0^{\circ} \mathrm{C}$ divides the remaining area into two warm regions closely paralleling the SST distribution. Surface salinity is relatively low in the western warm region and a strong salinity front lies roughly along the $21.0^{\circ} \mathrm{C}$ isotherm west of $131^{\circ} \mathrm{E}$. The path of the EKWC can be clearly seen in the distribution of $\theta$ and salinity at $100 \mathrm{~dB}$. The EKWC carrying water of high temperature and salinity $\left(\theta>12.0^{\circ} \mathrm{C}, \mathrm{S}>34.3\right)$ flows northeastward after separating from the coast around $36.5^{\circ} \mathrm{N}$. Multiple bifurcations of the EKWC occurs on its way towards the northeast. Part of the flow forms an elongated eddy (UWE) southwest of Ulleungdo. The remainder turns to the south in an area north of Ulleungdo and flows to the southwest passing through the UIG, thus forming a large anticyclonic meandering. The UWE constitutes the interior of the meandering.

The meandering of the EKWC can also be seen in the trajectory of an Argos surface drifter (Fig. 10). The drifter initially launched close to the east coast of Korea on July 1 followed meandering EKWC after it experienced about 1.5 cyclonic turns between the EKWC and the east coast

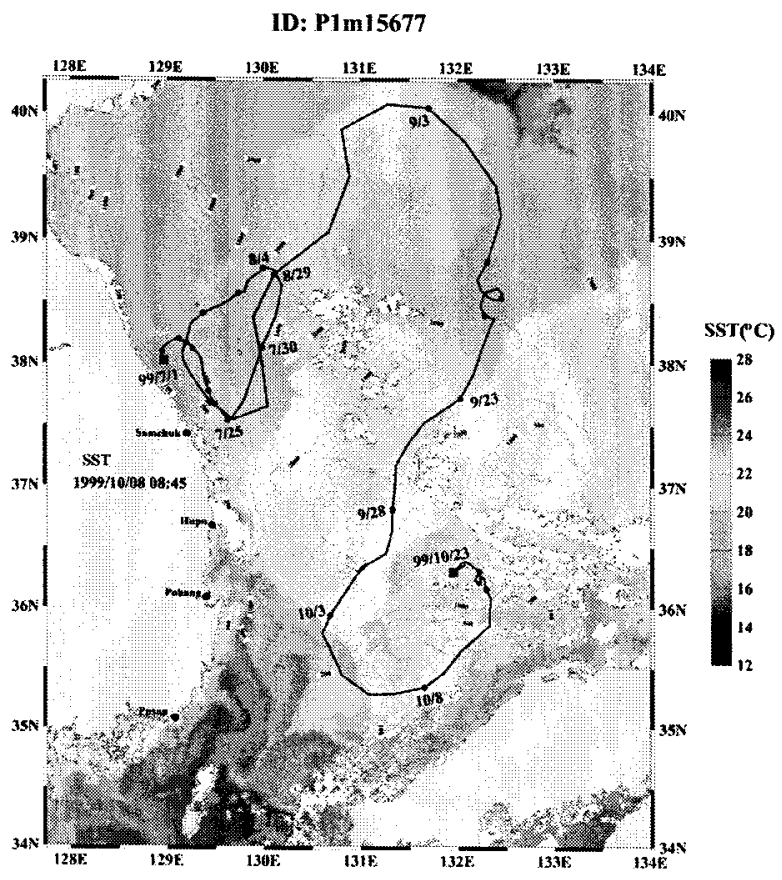

Fig. 10. Trajectory of a satellite-tracked surface drifter (Argos buoy) between July 1 and October 23, 1999. Positions at every 5 days are marked with solid dots. of Korea. It turned anticyclonically at about $40^{\circ} \mathrm{N}$ with a high speed of about $50-60 \mathrm{~cm} / \mathrm{s}$, and moved southwestward approximately following the relatively cold water region seen in the satellite image. It took about one month for the drifter to move from the northernmost location at about 40 ' $\mathrm{N}$ to the trough of the meander located around $35.5^{\circ} \mathrm{N}$. The speed of the southward EKWC was about $30 \mathrm{~cm} / \mathrm{s}$.

The EKWC water forms a strong thermal front together with both the coastal water north of $37^{\circ} \mathrm{N}$ and water around Dokdo that are colder and less saline than the EKWC water (Fig. 9). If the distributions of $\theta$ and $S$ at $100 \mathrm{~dB}$ in Oct. 1999 is compared with those in Aug. 1996 shown in Fig. 6, the cold coastal water in Aug. 1996 occupied the wider area than in Oct. 1999 and the TC shifted more to the east in Aug. 1996. Hence, the path of the TC appears to be affected by the development of the cold coastal water. The cold water region northeast of Dokdo was also wider in Aug. 1996 than in Oct. 1999.

The sea area around Dokdo lies in the eastern part of the meandering crest, and water around it is relatively cold and less saline at $100 \mathrm{~dB}$. The detailed horizontal distribution of water properties around Dokdo indicate that while temperature and salinity at $10 \mathrm{~dB}$ are highest in the southern and eastern regions of Dokdo and decreases to the northwest, they are lower in the southeastern Dokdo than in the northwestern Dokdo at deeper depths (Fig. 11). Dynamic topography at $10,50,100$, and $200 \mathrm{~dB}$ referred to $500 \mathrm{~dB}$ surface is high in the northwestem Dokdo and low in the southeastern Dokdo, suggestive of the southwestward flow referred to $500 \mathrm{~dB}$ surface consistent with the surface current observed by the drifter. Topographically-induced small scale meandering and eddies can also be seen in the Dokdo vicinity.

Figure 12 show the vertical sections of $\theta$ and salinity along a line running from the northwest to southeast in the Dokdo vicinity. Isolines slope upwards to Dokdo in the northwestern Dokdo and more or less flat in the southeastern Dokdo. Due to the shallow topography, isotherms are locally lifted around station A0. The tilting of isolines in the northwestern Dokdo suggests an southwestward flow that is consistent with the surface current revealed by the trajectory of the drifter and inferred from the property distributions at $100 \mathrm{~dB}$. Salty water with salinity higher than 34.3 appears at around $50 \mathrm{~dB}$ below the seasonal halocline. The high salinity core is not captured at $100 \mathrm{~dB}$, as it lies above the $100 \mathrm{~dB}$ around Dokdo. The shallowness of the high salinity core layer around Dokdo is due to the fact that the Dokdo area is located in the eastern side of the meandering EKWC as shown in Fig. 9. 


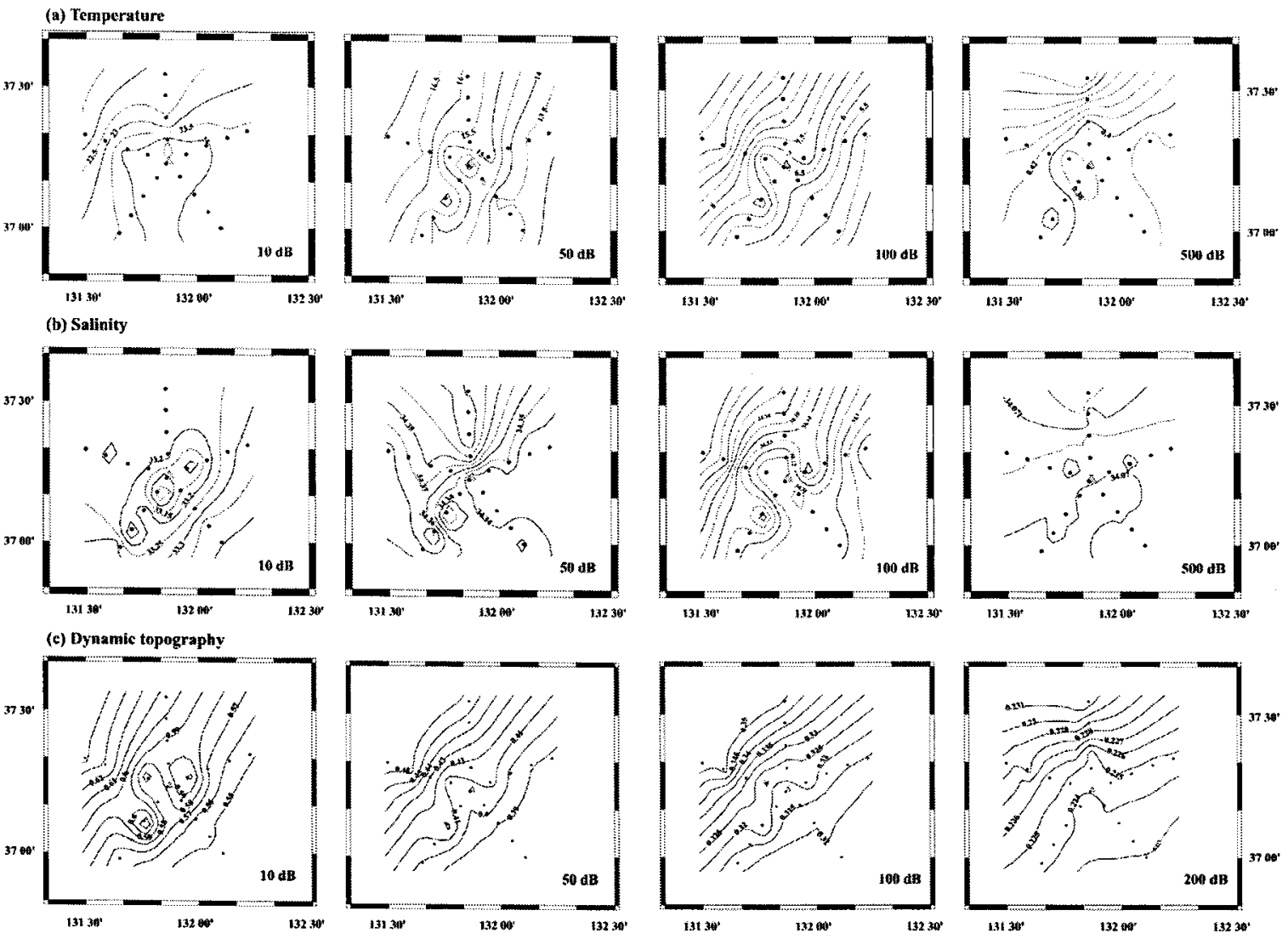

Fig. 11. Horizontal distribution of (a) potential temperature and (b) salinity at $10 \mathrm{~dB}, 50 \mathrm{~dB}, 100 \mathrm{~dB}$, and $500 \mathrm{~dB}$ around Dokdo between September 28 and October 2, 1999. (c) Dynamic depth anomaly at $10 \mathrm{~dB}, 50 \mathrm{~dB}, 100$ $\mathrm{dB}$, and $200 \mathrm{~dB}$ referred to $500 \mathrm{~dB}$ surface.

\section{0, 2001}

CTD surveys across the UIG were conducted three times in May, Sept., and Nov. in 2000, and two times in April and Oct. in 2001. The survey in May 2000 included a wide area in the UB and closely spaced stations in the southern Dokdo as well as in the UIG.

The horizontal distribution of $\theta$ and salinity at $5 \mathrm{~dB}$ and $100 \mathrm{~dB}$ in May 2000 is shown in Fig. 13. Surface temperature is higher in the area south of $37^{\circ} \mathrm{N}$ than north of $37^{\circ} \mathrm{N}$ except an area off Ulsan. The coastal cold water off Ulsan is due to a local upwelling in the area that has been often observed especially in summer (Lee and $\mathrm{Na}$, 1985; Byun, 1989). Surface salty water is found in the northern part of the survey area including the area around Dokdo where the surface temperature is relatively low. The horizontal distribution of $\theta$ and salinity at $100 \mathrm{~dB}$ shows the thermohaline front is formed roughly along $130^{\circ} \mathrm{E}$. Cold and less saline coastal waters are found west of the fronts, indicative of the northward flowing TC. The TC bifurcates at $36^{\circ} \mathrm{N}$ with one turning to the east to form the
$\mathrm{OB}$ and the other flowing to the north as the EKWC. The EKWC shifts to offshore in the cold water area off Ulsan and approaches the coast north of $36^{\circ} \mathrm{N}$. The EKWC bifurcates at around $37.5^{\circ} \mathrm{N}$ with majority of flow exiting the UB to the north. The remainder turns anticyclonically to form the UWE. Cold and less saline water is found north of Dokdo.

The eastern part of the UWE is often captured in the UIG like in May 2000 and also in April 2001 with the former having a larger spatial scale (Figs. 14, 16b). The vertically homogeneous thermostad is then developed in the western UIG close to Ulleungdo and isolines slope upwards to Dokdo. The $10.0^{\circ} \mathrm{C}$ isotherm forms the lower boundary of the UWE and subsurface temperature below the $10.0^{\circ} \mathrm{C}$ isotherm becomes colder near Dokdo than near Ulleungdo. The spatial scale of the eddy affects the water characteristics near Dokdo. When the horizontal scale of the UWE is large like the case in May 2000, water temperature near Dokdo becomes warmer than the case in April 2001 when the spatial scale is smaller. High salinity 

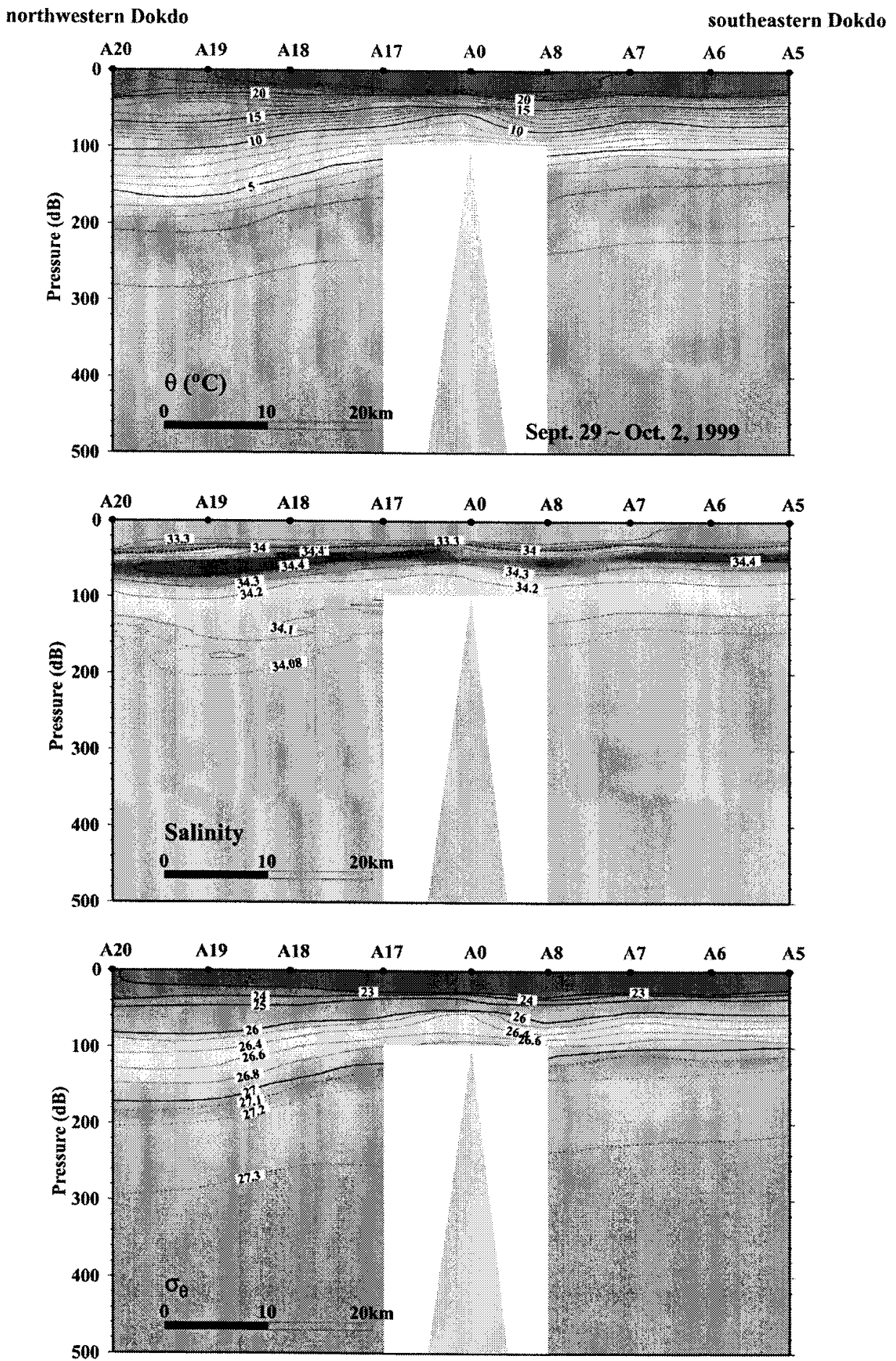

Fig. 12. Vertical distribution of potential temperature $(\theta)$, salinity, and potential density $\left(\sigma_{\theta}\right)$ along a section shown in Fig. 2b from the northwestern Dokdo to southeastern Dokdo in September-October 1999.

water $(34.3<\mathrm{S}<34.4)$ was found in the thermostad close to Ulleungdo in April 2001. On the other hand, the highest salinity ( $S>34.4$ ) occurred in the periphery of the eddy close to Dokdo in May 2000.

The thermostad was capped by surface warm and low salinity water and the eddy structure is spatially shrunken 
(a)
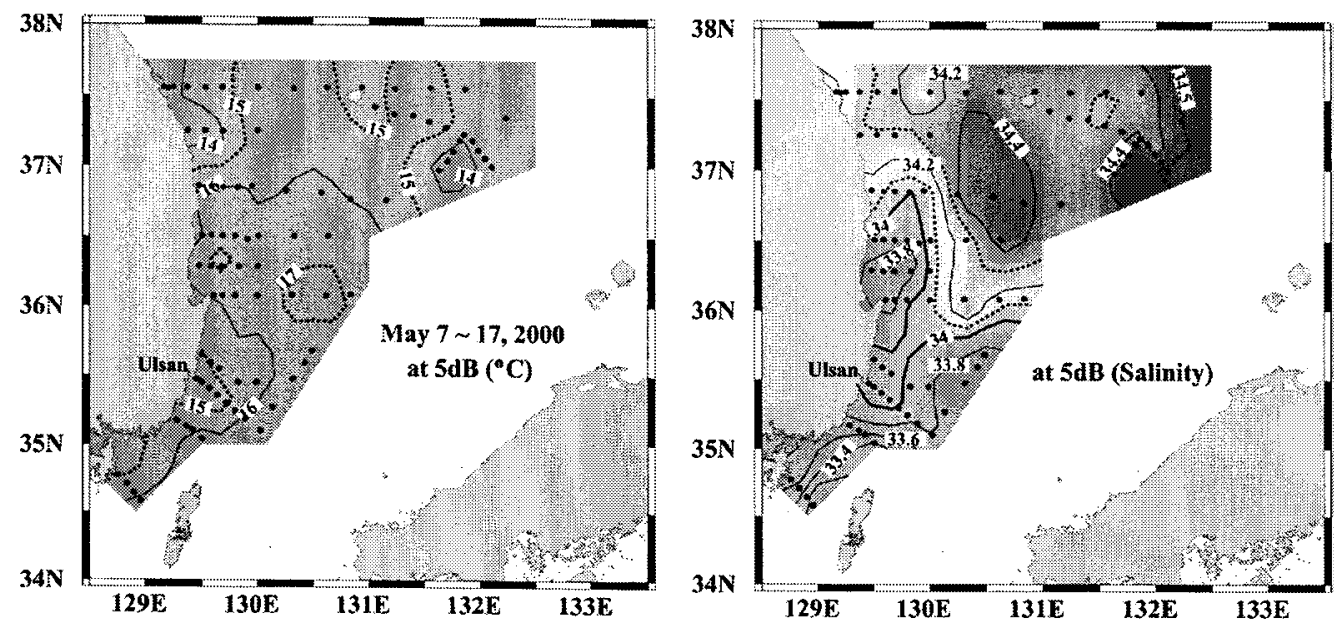

(b)
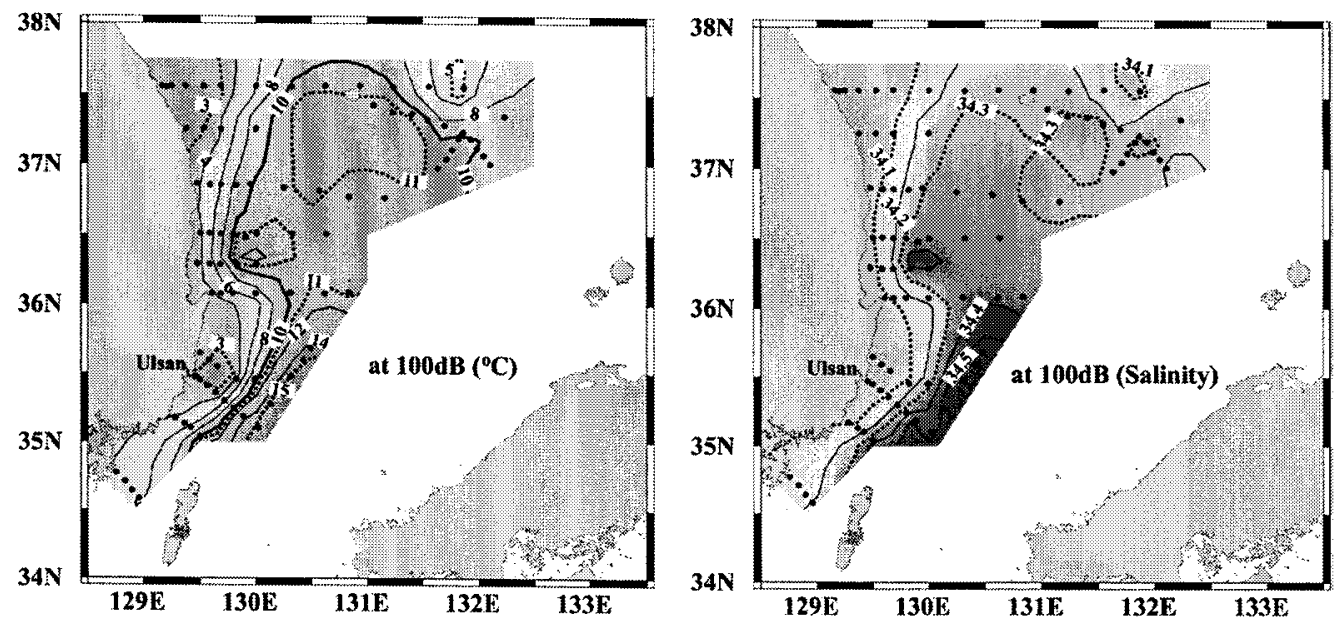

Fig. 13. Horizontal distribution of potential temperature (left panel) and salinity (right panel) at (a) $5 \mathrm{~dB}$ and (b) 100 dB in May 2000.

in Sept. 2000 although the bulge of isotherms and high salinity core are still discernible in the western UIG (Fig. 15a). Isolines slope upwards to the east similar to the trend in May 2000 but now with a reduced slope due to the decay of the eddy structure. The $10.0^{\circ} \mathrm{C}$ isotherm at station U8 off Dokdo was located at $83 \mathrm{~dB}$ in May 2000, but at $27 \mathrm{~dB}$ in Sept. 2000.

Along with this changes in the upper layer structure, a substantial freshening of the ESIW occurred in Sept. 2000 (Fig. 15a). The ESIW with salinity lower than 34.0 occupies a wide area in the UIG, and the lowest salinity value of 33.81 in the ESIW occurs at station U5 in Sept. 2000. Salinity of the ESIW in May 2000 was higher than 34.04 , and the thickness of the salinity minimum layer was much thinner than that observed in Sept. 2000. The maximum thickness of the ESIW with salinity less than 34.06 is about $220 \mathrm{~dB}$ at station U4 in Sept. 2000. Isotherms below the ESIW, especially the $0.7^{\circ} \mathrm{C}$ isotherm, are bowlshaped with its center at station U4 where the maximum thickness of the ESIW occurs. It is not clear whether or not the thickening and freshening of the ESIW in the UIG is associated with the changes in eddy structure above the ESIW.

A salinity maximum layer can be seen above $100 \mathrm{~dB}$ across the entire UIG in November 2000 (Fig. 15b). Salinity in the layer, however, is less than 34.3 and is lower than salinity both in May and September 2000. The UIG was neither influenced by the warm eddy nor the 

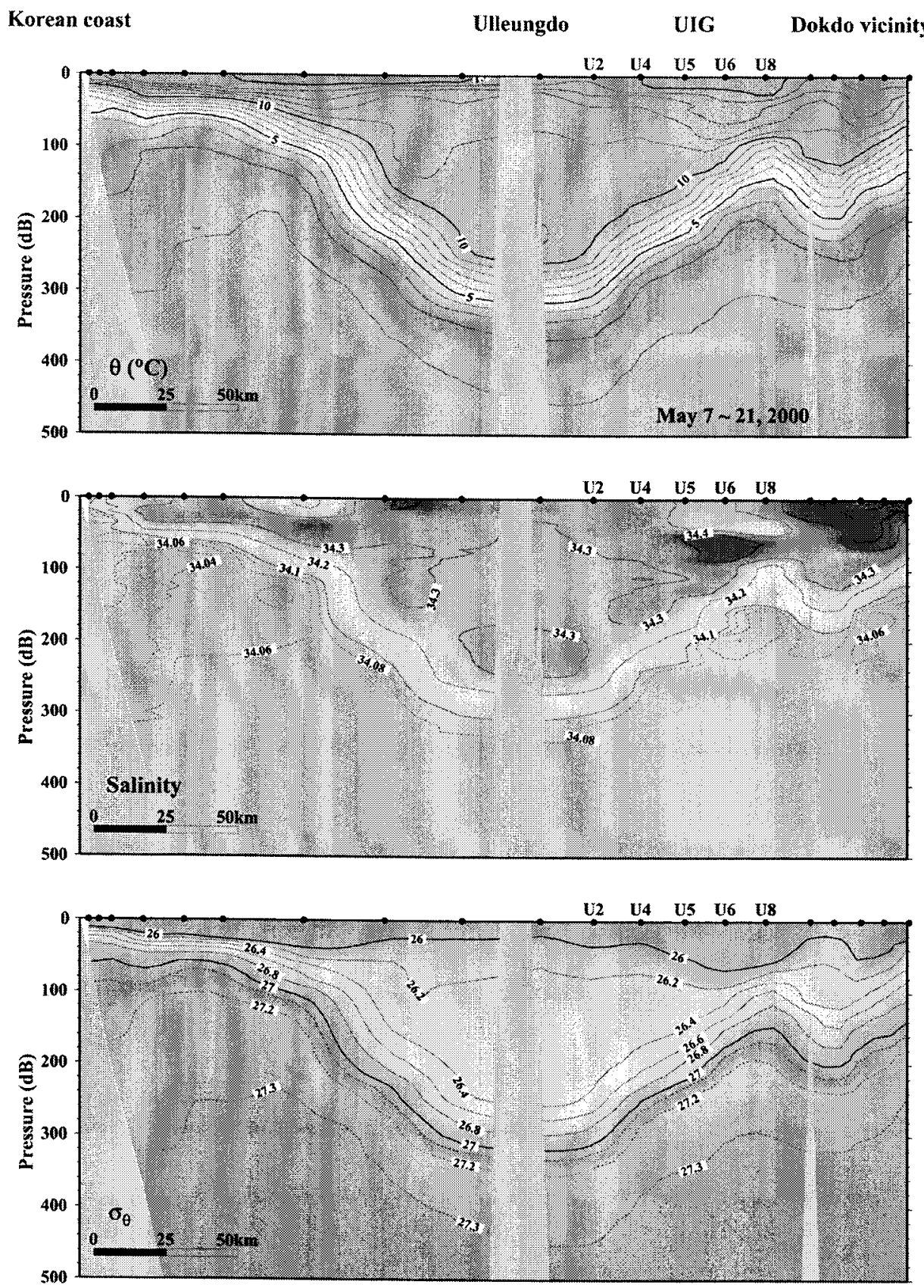

Fig. 14. Vertical distribution of potential temperature $(\theta)$, salinity, and potential density $\left(\sigma_{\theta}\right)$ along a section shown in Fig. $2 c$ from the east coast of Korea to the Dokdo vicinity in May 2000. UIG denotes the location of the Ulleung Interplain Gap.

newly derived TCW from the Korea Strait in November 2000 , and isolines are relatively flat in the upper $200 \mathrm{~dB}$. An anticyclonic eddy was observed south of the UIG and the area occupied by the saline TCW was confined farther south according to CTD data taken in a wide area in the UB in November 2000. The ESIW found in Nov. 2000 has also a very low salinity less than 34.0 as in Sept. 2000. The core layer of the ESIW was shifted to the west with a larger thickness in the western UIG in Sept. 2000, while it has a flat structure in Nov. 2000. The thickness of the ESIW, if defined by water with salinity less than 34.06 as in May 2000, is about $200 \mathrm{~dB}$ similar to the thickness in 
May 2000.

Continuous acoustic travel-time measurements showed that a cold phase persisted between June 17 and Nov. 5, 2000 in the upper layer in the UB that was characterized by the disappearance of the EKWC and a small UWE (Mitchell et al., 2002). The disappearance of the EKWC is also obvious from temperature distributions at $100 \mathrm{~m}$ based on data acquired in Aug. and Oct. 2000 by National

(a)
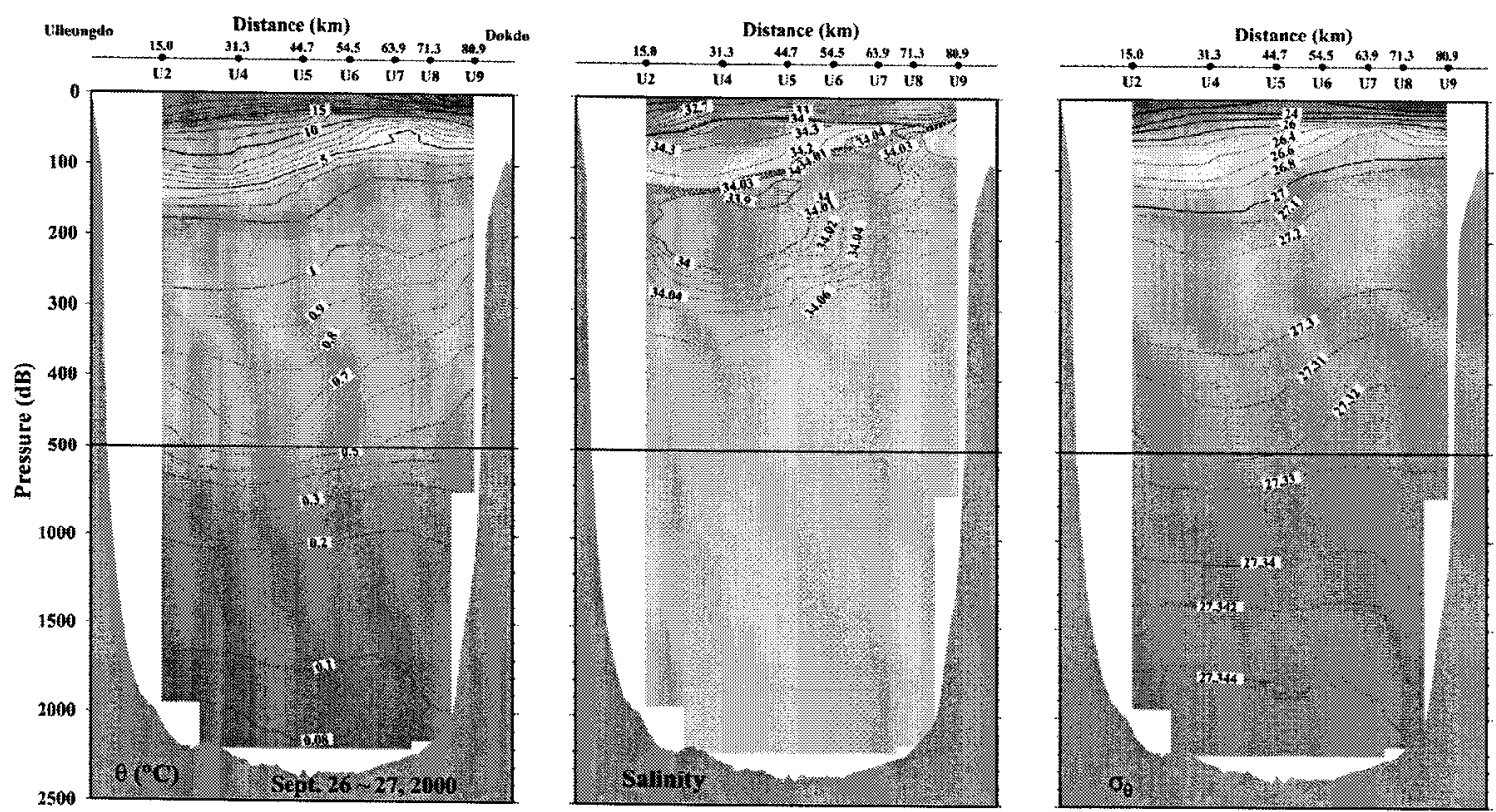

(b)
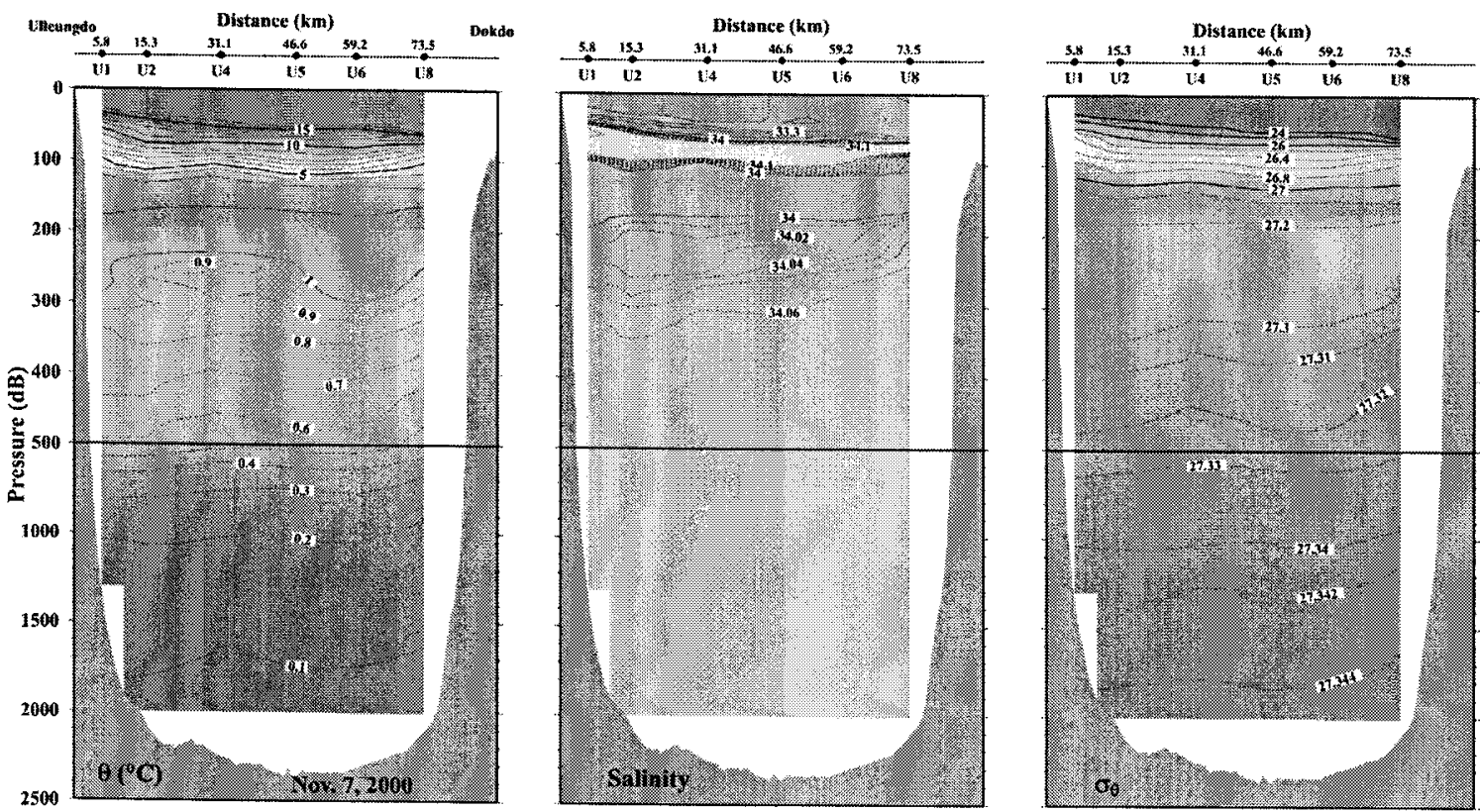

Fig. 15. Vertical distribution of potential temperature $(\theta)$, salinity, and potential density $\left(\sigma_{\theta}\right)$ across the Ulleung Interplain Gap between Ulleungdo and Dokdo in (a) September 2000 and (b) November 2000. The distance shown in the figure is measured from Ulleungdo to each station. 
Fisheries Research and Development Institute (not shown). The cold phase followed a warm phase with a larger UWE during Feb.-early June 2000 with a rather abrupt transition that occurred in mid June. The warm phase was recovered from the end of Nov. 2000 with a transition between Nov. 6 and Nov. 28. The occurrence of the cold phase was associated with the deep southward penetration of cold water northeast of Dokdo reaching the southeastern coast of Korea that hampered the development of the EKWC along the Korean coast. The low salinity ESIW in (a)

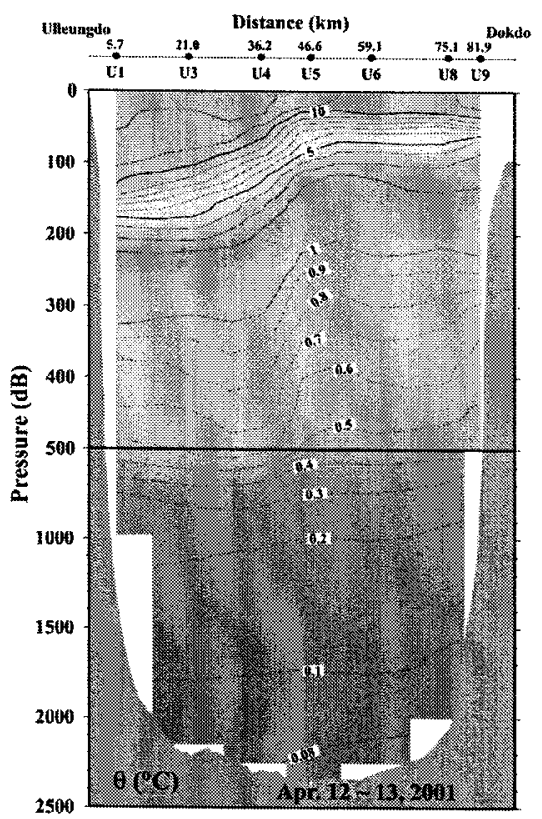

(b)

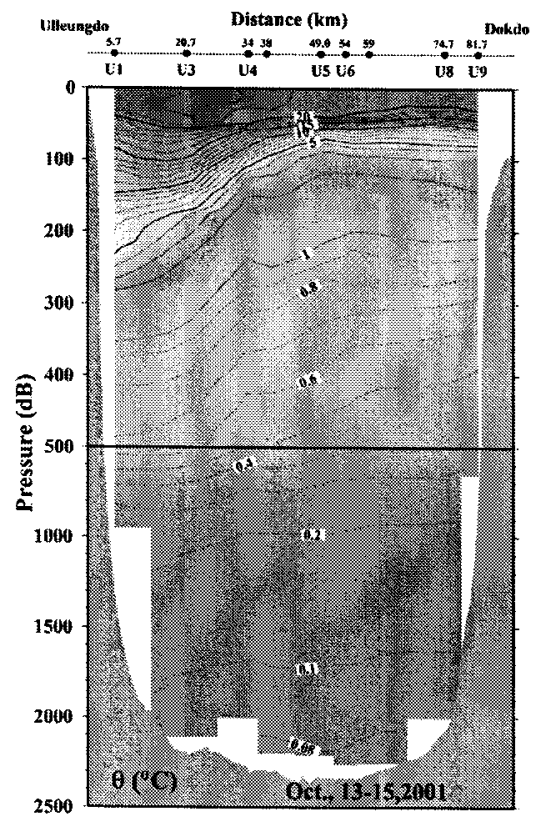

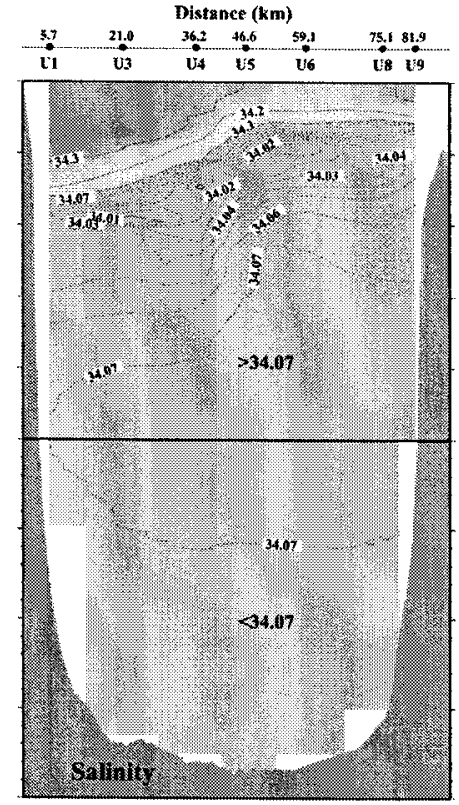
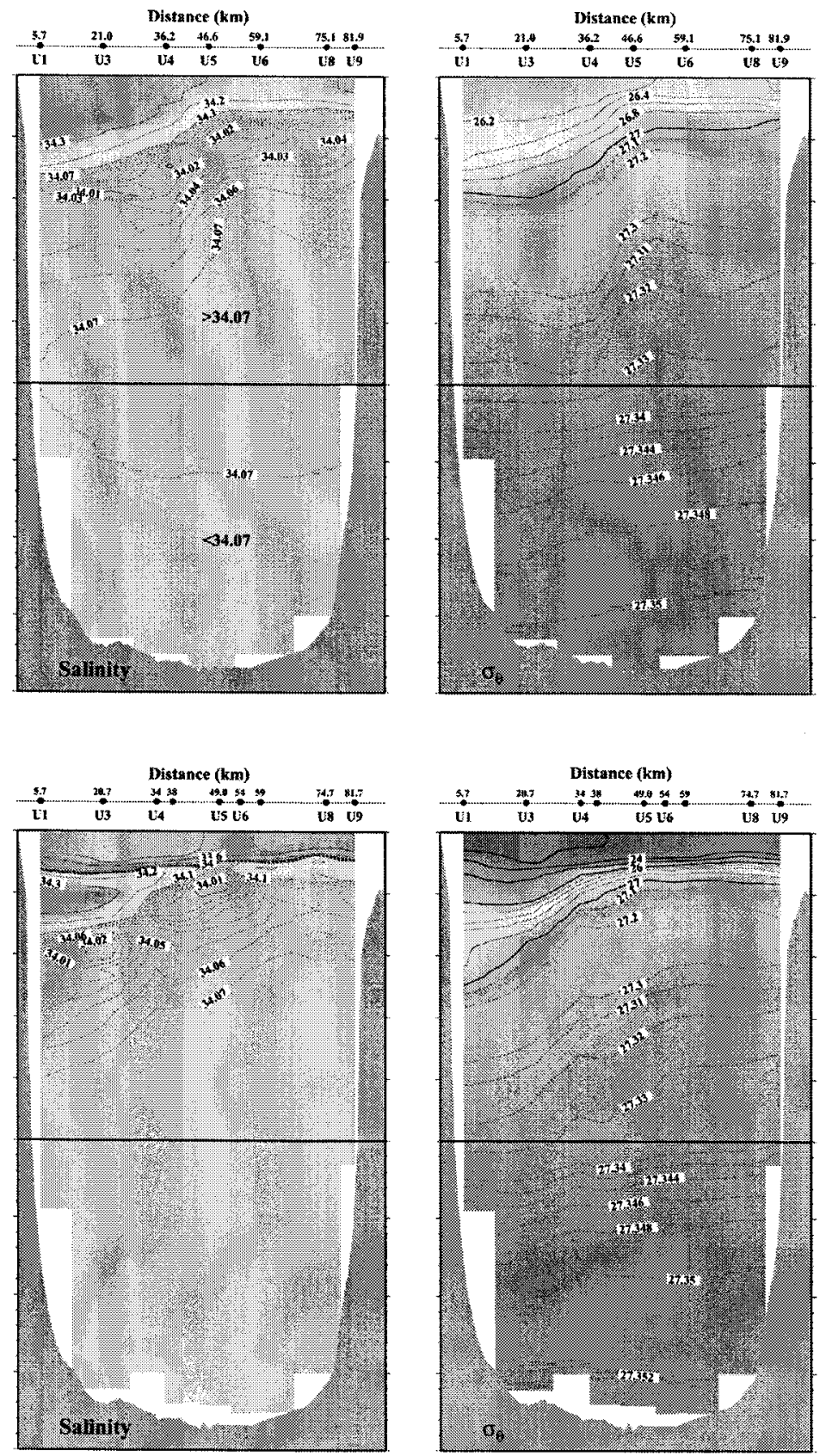

Fig. 16. Vertical distribution of potential temperature $(\theta)$, salinity, and potential density $\left(\sigma_{\theta}\right)$ across the Ulleung Interplain Gap between Ulleungdo and Dokdo in (a) April 2001 and (b) October 2001. The distance shown in the figure is measured from Ulleungdo to each station. 
the UIG observed in Sept. and Nov. 2000 appears to be brought into the area from the subpolar front by the southward penetration of the cold water.

A high salinity core of the TCW with salinity higher than 34.3 re-appeared in the western UIG close to Ulleungdo in April 2001 with a smaller size as compared to that found in May 2000 (Figs. 14, 16a). It was also found in Oct. 2001 in the same location as in April 2001 but now capped by warm and low salinity surface water. In Oct. 2001, temperature is higher and salinity is lower in the SML above the TCW as compared to those in the eastern UIG where the TCW is not found. The horizontal extent of the TCW is confined within about $40 \mathrm{~km}$ from Ulleungdo where isotherms slope upwards and become crowded to the east. The vertical section in Oct. 2001 is similar to that in Oct. 1998, but different from that observed in Oct. 1997 when water around Dokdo was directly fed by the TCW.

\section{Summary and discussion}

It has been shown that the hydrography around Dokdo is affected by the path variability and the meandering of the EKWC, the position of the $\mathrm{OB}$, the size and location of the UWE, and variability of the subpolar front northeast of Dokdo. It has been frequently observed that Dokdo lies in the eastern part of either the meandering EKWC or the UWE resulting in a tilting of isolines sloping upwards to Dokdo in the UIG like in Oct. 1998 (Fig. 8c), Sept. 1999 (Fig. 9), May 2000 (Fig. 14), Sept. 2000 (Fig. 15a), April (Fig. 16a) and Oct. 2001 (Fig. 16b). The meandering of the EKWC and the UWE associated with the meandering had a large spatial scale enough to warm up the Dokdo vicinity in May 2000. On the other hand, the meandering of the EKWC occurred with a sharp angle in Aug. 1996 and Sept. 1999 in areas west of Dokdo, and temperature around Dokdo becomes low due to the influence of the cold water northeast of Dokdo. Mitchell et al. (2002) called the cold water around Dokdo the Dok Cold Eddy, and showed it is highly variable in space and time and tends to propagate to the southwest towards the Korean coast when the subpolar front northeast of Dokdo meanders southward. Once the Dok Cold Eddy merges the cold water off the Korean coast, a cold phase emerges in the upper layer in the UB as was shown during JuneNov. 2000. The cold phase was characterized by the disappearance of the EKWC and the shrinking of the UWE. Vertical sections in the UIG taken during this cold phase show that the significant freshening of the ESIW occurred in the UIG (Fig. 15) which appears to be associated with a large southward meandering of the subpolar front.

Observations in April and Oct. 1997 showed that the vertical sections in the UIG becomes opposite to the cases observed in other times when the isolines generally slope upwards to Dokdo. The isolines slope upwards to Ulleungdo in the UIG and high salinity cores are found near Dokdo both in April and Oct. 1997. SST images indicate that the Dokdo area was affected by a small scale warm eddy fed by the OB in April and by the EKWC heading directly toward Dokdo after leaving the Korea Strait.

It is obvious that we need to elucidate the variability of the EKWC in order to understand the hydrography around Dokdo. One of the important factors causing the variability of the EKWC could be the transport variation of the TC through the Korea Strait. This was partly the case, although the EKWC exhibited three different patterns in the UB even though the transport of the TC changed little (Mitchell et al., 2002). Other factors affecting the variability of the EKWC would be the influence of cold waters found

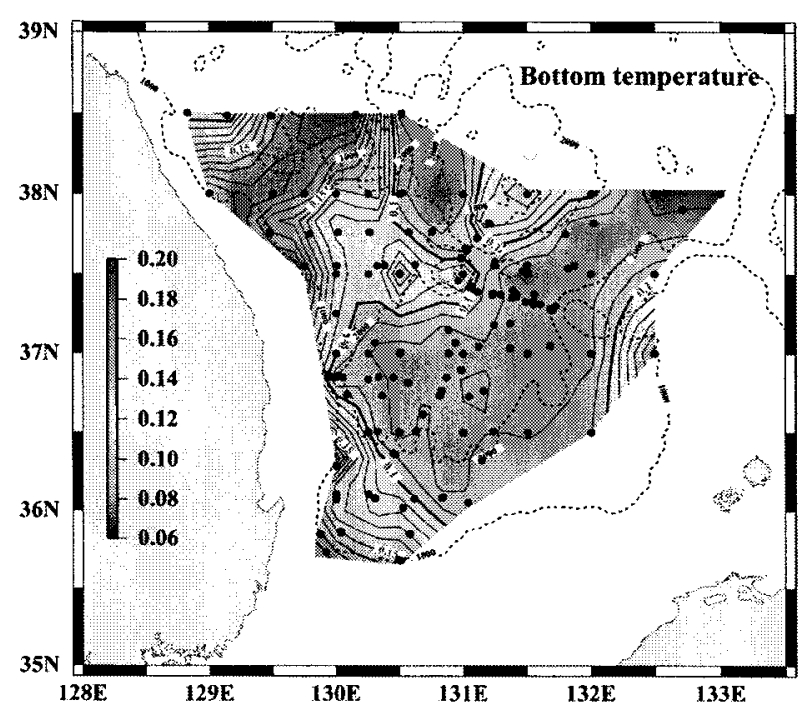

Fig. 17. Potential temperature near the seabed in the Ulleung Basin, showing the spreading of water of colder than $0.1^{\circ} \mathrm{C}$ in the Ulleung Basin through the Ulleung Interplain Gap and the narrow Ulleung Trough where water depth is deeper than $1500 \mathrm{~m}$. Water of colder than $0.1^{\circ} \mathrm{C}$ (the East Sea Deep and Bottom Waters) is not found on the Korea Plateau between the eastern coast of Korea and Ulleungdo where water depth is shallower than $2000 \mathrm{~m}$. This climatology was compiled from all available KORDI's CTD casts since 1996. 
off the Korean coast and/or the meandering of the subpolar front that brings cold water northeast off Dokdo to the south. Volume transport of the TC through the Korea Strait has been monitored since 1998 by measuring voltage on a submarine cable spanning the entire strait (Lyu et al., 2002). More observational efforts that can resolve mesoscale variability in time and space are needed in the UIG and around Dokdo to understand and monitor the variability of the EKWC and subpolar front in connection with the transport monitoring through the Korea Strait.

The ESPW defined by water of colder than $1.0^{\circ} \mathrm{C}$ occupies about $90 \%$ of total water volume in the East Sea. The ESPW originating from the $\mathrm{JB}$ is also found in the UB that reaches the UB over the Korea Plateau and through the UIG. The ESPW in the Japan Basin was found to consist of four different water masses based on precise measurements of temperature and salinity (Kim et al., 1996). Among them, the East Sea Deep and Bottom Waters (referred to as ESDW hereafter) whose $\theta$ are lower than $0.1^{\circ} \mathrm{C}$ enter into the UB only through the UIG that is evidenced by the horizontal distribution of $\theta$ near the bottom in the UB (Fig. 17). The ESDW occupies a wide area in the UB where water depth is deeper than about $1500 \mathrm{~dB}$. It is not found over the Korea Plateau, and found in the UIG and in the narrow Ulleung Trough. Long-term current measurements at a location in the mid-UIG show a rather steady southwestward deep flow (Chang et al., 2002a). If the ESDW is assumed to enter into the UB through the entire section across the UIG, then the heat and mass balances yield the vertical diffusivity of an order of $10^{-3} \mathrm{~m}^{2} \mathrm{~s}^{-1}$ suggestive of the substantial diapycnal mixing across the top layer of the ESDW (Chang et al., 2002b). The inflow of the ESDW, on average, circulates cyclonically in the UB (Teague et al., 2002) which could be driven by the net inflow into the UB through the stretching implied at the top of the ESDW layer. To quantify an exact amount of inflow transport, hence, is important in understanding the deep circulation and diapycnal mixing in the UB. Especially, deep current measurements are required close to Dokdo since a fine-resolution numerical model predicts an outflow of part of the deep water near Dokdo (Hogan and Hurlburt, 2000).

\section{Acknowledgements}

Suggestions and comments by two reviewers, Dr. C.-H. Kim and Prof. H.-R. Shin improved our paper. We thank Professor Dong-Kyu Lee for providing the Argos drifter data. This study was supported by grants from KORDI's in-house projects (BSPN 00316-963-1, BSPE 817-001396-1) and from the Korea Ministry of Maritime Affairs and Fisheries (BSPM 99045-00-1282-6).

\section{References}

An, H.S., K.S. Shim, and H.R. Shin. 1994. On the warm eddies in the southwestern part of the East Sea. J. Korean Soc. Oceanogr, 29, 152-163.

Byun, S.-K. 1989. Sea surface cold water near the southeastern coast of Korea: Wind effect. J. Oceanol. Soc. Korea, 24, 121-131.

Chang, K.-I., N. Hogg, M.-S. Suk, S.-K. Byun, K. Kim, and Y.-G. Kim. 2002a. Mean flow and variability in the southwestern East Sea. Deep-Sea Res. Part I (in press).

Chang, K.-I., Y.-B. Kim, and M.-S. Suk. 2002b. The flux and mixing rate of the East Sea Deep Water in the Ulleung Basin. p. 18-21. In: Proceedings of the Spring Meeting, 2002 of the Korean Society of Oceanography, Kwangju, Korea, May 9-11.

Cho, K.-D., T.-J. Bang, T.-B. Shim, and H.-S. Yu. 1990. Three dimensional structure of the Ulleung Warm Lens. Bull. Korean Fish. Soc., 23, 323-333.

Cho, Y.-K. and K. Kim. 1995. Two modes of the salinityminimum layer water in the Ulleung Basin. La Mer, 33, 33-40.

Hase, H., J.-H. Yoon, and W. Koterayama. 1999. The current structure of the Tsushima Warm Current along the Japanese coast. J. Oceanogr., 55, 217-236.

Hogan, P.J. and H.E. Hurlburt. 2000. Impact of upper oceantopography coupling and isopycnal outcropping in Japan/ East Sea models with $1 / 8^{\circ}$ to $1 / 64^{\circ}$ resolution. J. Phys. Oceanogr., 30, 2535-2561.

Kawabe, M. 1982. Branching of the Tsushima Current in the Japan Sea, Part I. Data analysis. J. Oceanol. Soc. Japan, 38, 95-107.

Kim, C.-H. and K. Kim. 1983. Characteristics and origin of the cold water mass along the east coast of Korea. $J$. Oceanol. Soc. Korea, 18, 73-83.

Kim, K. and J.-Y. Chung. 1984. On the salinity minimum layer and dissolved oxygen-maximum layer in the East Sea (Japan Sea). p. 55-65. In: Ocean Hydrodynamics of the Japan and East China Seas, ed. by T. Ichiye, Elsevier, Amsterdam.

Kim, K., K.-R. Kim, J.-Y. Chung, H.-S. Yoo, and S.-G. Park. 1991. Characteristics of water properties in the Ulleung Basin. J. Oceanol. Soc. Korea, 26, 83-100.

Kim, K., Y.-G. Kim, Y.-K. Cho, M. Takematsu, and Y. Volkov. 1999. Basin-to-basin and year-to-year variation of temperature and salinity characteristics in the East Sea (Sea of Japan). J. Oceanogr., 55, 103-109.

Kim, K., K.-R. Kim, Y.-G. Kim, Y.-K. Cho, J.-Y. Chung, B.H. Choi, S.-K. Byun, G.-H. Hong, M. Takematsu, J.-H. Yoon, Y. Volkov, and M. Danchenkov. 1996. New findings from CREAMS observations: Water masses and eddies in the East Sea. J. Korean Soc. Oceanogr., 31, 
155-163

Kim, Y.-G. and K. Kim. 1999. Intermediate waters in the East/Japan Sea. J. Oceanogr., 55, 123-132.

Kim, Y.G., K. Kim, Y.-K. Cho, and H. Ossi. 2000. CTD data processing for CREAMS expeditions: Thermal-lag correction of Sea-Bird CTD. J. Korean Soc, Oceanogr., 192-199.

Lee, J.C. and J.Y. Na. 1985. Structure of upwelling off the southeast coast of Korea. J. Oceanol. Soc. Korea, 20, 6-19.

Lie, H.-J., S.-K. Byun, I. Bang, and C.H. Cho. 1995. Physical structure of eddies in the southwestern East Sea. $J$. Korean Soc. Oceanogr., 30, 170-183.

Lyu, S.J., K. Kim, Y.-G. Kim, B.H. Choi, T. Taira, H.T. Perkins, W.J. Teague and J.W. Book. 2002. Monitoring volume transport through measurement of cable voltage across the Korea Strait. Submitted to J. Atmos. Oceanic Technol.

Mitchell, D.A., J.W. Book, K.-I. Chang, M.-S. Suk, W.J. Teague, K.L. Tracey, D.R. Watts, M. Wimbush, and J.-H. Yoon. 2002. Upper circulation patterns in the southwestern Japan/East Sea. Submitted to Deep-Sea Res.

Nitani, H. 1972. On the deep and bottom waters in the Japan Sea. p. 151-201. In: Research in Hydrography and Oceanography, ed. by D. Shoji. Hydrographic Department of Japan.
Shin, C.-W., S.-K. Byun, C. Kim, and Y.-H. Seung. 1998. Southward intrusion of the East Sea Intermediate Water into the Ulleung Basin: Observations in 1992 and 1993. J. Korean Soc. Oceanogr., 33, 146-156.

Shin, H.-R., S.-K. Byun, and C. Kim. 1995. The characteristics of structure of warm eddy observed to the northwest of Ullungdo in 1992. J. Korean Soc. Oceanogr., 30, 39-56 (in Korean with English abstract).

Suh, Y.S., B.G. Mitchell, and K.S. Lim. 1999. A recurring eddy off the Korean northeast coast captured on satellite ocean color and sea surface temperature imagery. $J$. Korean Soc. Remote Sensing, 15, 175-181.

Teague, W.J., D.R. Watts, J.W. Book, K.-I. Chang, P.J. Hogan, D.A. Mitchell, M.-S. Suk, K.L. Tracey, M. Wimbush, and J.-H. Yoon. 2002. Deep circulation in the southwestern Japan/East Sea. Submitted to Deep-Sea Res.

Uda, M. 1934. Oceanographic conditions in the Japan Sea and its adjacent waters (the result of simultaneous oceanographical investigations in the Japan Sea and its adjacent waters in May and June, 1932). J. Imp. Fish. Exp. St., 5, 57-190 (in Japanese with English abstract).

Received Nov. 25, 2002

Accepted Dec. 24, 2002 